\title{
An Unconventional Secretory Pathway Mediates the Cilia Targeting of Peripherin/rds
}

\author{
Guilian Tian, Philip Ropelewski, Ina Nemet, Richard Lee, Kerrie H. Lodowski, and Yoshikazu Imanishi \\ Department of Pharmacology, School of Medicine, Case Western Reserve University, Cleveland, Ohio 44106-4965
}

It is unclear how unconventional secretion interplays with conventional secretion for the normal maintenance and renewal of membrane structures. The photoreceptor sensory cilium is recognized for fast membrane renewal, for which rhodopsin and peripherin/rds (P/rds) play critical roles. Here, we provide evidence that $\mathrm{P} / \mathrm{rds}$ is targeted to the cilia by an unconventional secretion pathway. When expressed in ciliated hTERT-RPE1 human cell line, $\mathrm{P} / \mathrm{rd}$ is localized to cilia. Cilium trafficking of $\mathrm{P} / \mathrm{rds}$ was sustained even when the Golgi functions, including trans-Golgi-mediated conventional secretion, were inhibited by the small molecules brefeldin A, 30N12, and monensin. The unconventional cilia targeting of P/rds is dependent on COPII-mediated exit from the ER, but appears to be independent of GRASP55mediated secretion. The regions in the C-terminal tail of $\mathrm{P} / \mathrm{rds}$ are essential for this unconventional trafficking. In the absence of the region required for cilia targeting, $\mathrm{P} / \mathrm{rds}$ was prohibited from entering the secretory pathways and was retained in the Golgi apparatus. A region essential for this Golgi retention was also found in the $\mathrm{C}$-terminal tail of $\mathrm{P} / \mathrm{rds}$ and supported the cilia targeting of $\mathrm{P} / \mathrm{rds}$ mediated by unconventional secretion. In ciliated cells, including bovine and Xenopus laevis rod photoreceptors, $\mathrm{P} / \mathrm{rds}$ was robustly sensitive to endoglycosidase $\mathrm{H}$, which is consistent with its bypassing the medial Golgi and traversing the unconventional secretory pathway. Because rhodopsin is known to traffic through conventional secretion, this study of $\mathrm{P} /$ rds suggests that both conventional secretion and unconventional secretion need to cooperate for the renewal of the photoreceptor sensory cilium.

Key words: cilia; peripherin/rds; photoreceptor; retina; trafficking; unconventional secretion

\section{Introduction}

The sensory primary cilium of vertebrate photoreceptor cells houses thousands of photosensitive disk membranes that are renewed continuously throughout our lifespan. Cilia targeting of Peripherin/rds (P/rds; Arikawa et al., 1992) is assumed to be essential for disk membrane morphogenesis and renewal (Farjo et al., 2006). Rds/rds mice lacking functional $\mathrm{P} / \mathrm{rds}$ are incapable of forming disks (van Nie et al., 1978; Travis et al., 1989). This disk membrane deficiency is one of the most severe among the retinal degeneration models and is comparable to rhodopsin knock-out mice that are also incapable of forming disks. One piece of evi-

\footnotetext{
Received Aug. 10, 2013; revised Nov. 27, 2013; accepted Dec. 4, 2013.

Author contributions: G.T. and Y.I. designed research; G.T.,P.R., and R.L. performed research; K.H.L. contributed unpublished reagents/analytic tools; G.T., P.R., I.N., and Y.I. analyzed data; G.T. and Y.I. wrote the paper.

This work was supported by the National Institutes of Health (Grants EY020826, EY011373, and DK007319). We thank Robert S. Molday for full-length bovine peripherin/rds cDNA and mouse mAb anti-X. Iaevis peripherin/rds; Kirk Mykytyn for pEGFPn-SSTR3 vector and IMCD3 cells; Brian Kevany for mouse mAb anti-bovine peripherin/rds; Vera Moiseenkova-Bell for rhodopsin antibody; Theodorus W.J. Gadella, Jr. and Antoine Royant for the pmTurquoise2Golgi vector; Min Goo Lee for pClneo-Sar1-Myc and pCIneo-Sar1(H79G)-Myc vectors; and Hisashi Fujioka, director of the Electron Microscopy Core Facility at CWRU, for his support on immunoelectron microscopy. The mouse mAb anti-ATPase $\mathrm{Na}^{+} / \mathrm{K}^{+} \alpha 5$ (developed by Douglas M. Fambrough) and the mouse mAb anti-beta-tubulin E7 (developed by Michael Klymkowsky) were obtained from the Developmental Studies Hybridoma Bank developed under the auspices of the Eunice Kennedy Shriver National Institute of Child Health and Human Development and maintained by The University of lowa, Department of Biology, lowa City, lowa.

The authors declare no competing financial interests.

Correspondence should be addressed to Yoshikazu Imanishi, Department of Pharmacology, School of Medicine, Case Western Reserve University, 2109 Adelbert Road, Wood Building, Cleveland, OH 44106-4965. E-mail: yxi19@case.edu.

DOI:10.1523/JNEUROSCI.3437-13.2014

Copyright $\odot 2014$ the authors $\quad 0270-6474 / 14 / 340992-15 \$ 15.00 / 0$
}

dence suggests that $\mathrm{P} / \mathrm{rds}$ and rhodopsin are trafficked through different routes. In detached cat retinas undergoing degeneration, $\mathrm{P} / \mathrm{rds}$ mislocalized to cytoplasmic vesicles, whereas rhodopsin mislocalized to the plasma membrane of photoreceptor cells (Fariss et al., 1997). Even though it was obtained under a pathological condition, this observation led to the hypothesis that $\mathrm{P} / \mathrm{rds}$ is transported by a mechanism distinct from that of rhodopsin.

Most plasma membrane proteins are sorted by the trans-Golgi network (TGN) in the conventional secretory pathway. As glycoproteins pass through the Golgi apparatus, most receive a mature, complex oligosaccharide. $\mathrm{P} / \mathrm{rds}$, an $\mathrm{N}$-linked glycoprotein, does not acquire a complex oligosaccharide and, accordingly, the oligosaccharide group of $\mathrm{P} / \mathrm{rds}$ is endoglycosidase $\mathrm{H}$ (Endo $\mathrm{H}$ )sensitive (Connell and Molday, 1990). This Endo H sensitivity indicates that $\mathrm{P} / \mathrm{rds}$ was not processed by Golgi mannosidase II (GMII), which is localized to the medial- to trans-Golgi apparatus (Velasco et al., 1993; Rabouille et al., 1995) and is thus possibly a sign of $\mathrm{P} / \mathrm{rds}$ trafficking through an unconventional secretory pathway. Unconventional secretory pathways are poorly defined secretory routes that do not require the TGN for sorting (Yoo et al., 2002; Schotman et al., 2008; Gee et al., 2011; Giuliani et al., 2011; Grieve and Rabouille, 2011; Hoffmeister et al., 2011). If unconventional secretion were to mediate the cilia trafficking of $\mathrm{P} / \mathrm{rds}$, then cooperation with the conventional secretory pathway that mediates the trafficking of rhodopsin would be required to ensure proper morphogenesis of the photoreceptive disk membranes.

Here, we tested the hypotheses that $\mathrm{P} / \mathrm{rds}$ is trafficked through an unconventional secretory pathway bypassing the Golgi appa- 
ratus either partly or entirely and that such an unconventional pathway also plays an important role in the targeting of $\mathrm{P} / \mathrm{rds}$ to the cilia and subsequently to the disk membrane. With the goal of elucidating the regions required for the specific localization of $\mathrm{P} / \mathrm{rds}$, we dissected the C-terminal (CT) tail, where the ciliatargeting signal is considered to reside (Tam et al., 2004; Salinas et al., 2013). These studies were conducted using mammalian cells that form primary cilia in culture. The roles of the CT tail region were further investigated using Xenopus laevis photoreceptor cells in vivo. These studies unveil a previously unknown role of an unconventional secretory pathway in the process of photoreceptor membrane morphogenesis and maintenance and also reveal the CT regions that act in a coordinated fashion to accomplish the unconventional cilia targeting of $\mathrm{P} /$ rds.

\section{Materials and Methods}

Constructs. Full-length bovine $\mathrm{P} / \mathrm{rds}$ (bP/rds) cDNA was a generous gift from Dr. Robert S. Molday (Department of Biochemistry and Molecular Biology, University of British Columbia, Vancouver, Canada). The coding region of $\mathrm{bP} / \mathrm{rds}$ was subcloned into $\mathrm{pMSCV}$ vector with $\mathrm{HA}$ and FLAG tag following the CT tail for expression in cell culture. bP/rdsDend 2 was generated by fusing Dendra2 (Dend2; Clontech Laboratories) to the $\mathrm{CT}$ tail of $\mathrm{bP} / \mathrm{rds}$. pcDNA3.3-bP/rds was generated by inserting $\mathrm{bP} / \mathrm{rds}$-coding region into $\mathrm{pcDNA} 3.3$ using the $\mathrm{XhoI}$ site. X. laevis $\mathrm{P} / \mathrm{rds}$ (xP/rds) cDNA (GeneBank ID\#: AY062004, Rds38) was obtained from $X$. laevis messenger RNA by reverse transcription and further cloned into TOPO vector with $X$. laevis rhodopsin promoter and fused with Dend2 following the CT tail. Different deletions of $\mathrm{bP} / \mathrm{rds}$ and $\mathrm{xP} / \mathrm{rds}$ were generated by the QuikChange site-directed in vitro mutagenesis kit (Stratagene) and subcloning. They were either fused to HA and FLAG epitopes or Dend2 fluorescent protein. pEGFPn-SSTR3 was a generous gift from Dr. Kirk Mykytyn (Department of Pharmacology, Division of Human Genetics, and College of Medicine, The Ohio State University, Columbus, $\mathrm{OH}$ ). pClneo-Sar1-Myc and pClneo-Sar1(H79G)-Myc vectors were generous gifts from Dr. Min Goo Lee (Yonsei University College of Medicine, Seoul, Korea). pmTurquoise2-Golgi was obtained from Addgene (plasmid 36205; Addgene), which includes the human trans-Golgi $\beta-1$, 4-galactosyltransferase $1(1-61)$ gene and the mTurquoise 2 fluorescent protein (Goedhart et al., 2012). For labeling Golgi apparatus of X. laevis rods, glycosyltransferase and mTurquoise 2 were subcloned into TOPO vector with the X. laevis arrestin promoter and the SV40 polyadenylation signal.

Cell culture. hTERT-RPE1cells (ATCC) were grown in the medium recommended by ATCC including DMEM/F12 with $10 \%$ fetal bovine serum, $0.01 \mathrm{mg} / \mathrm{ml}$ hygromycin $\mathrm{B}$, and $1 \%$ penicillin/streptomycin at $37^{\circ} \mathrm{C}$ with $5 \% \mathrm{CO}_{2}$. Inner medullary collecting duct 3 (IMCD3) cells were cultured in DMEM/F12 with $10 \%$ FBS and $1 \%$ penicillin/streptomycin at $37^{\circ} \mathrm{C}$ with $5 \% \mathrm{CO}_{2}$. To induce cilia, cells were incubated in DMEM/F12 without FBS along with $0.3 \mu \mathrm{M}$ Cytochalasin D (Cyto D; Sigma-Aldrich) for $16 \mathrm{~h}$ to maximize the probability of ciliogenesis by a combination of serum starvation and mild perturbation of the actin cytoskeleton (Kim et al., 2010). For some of the experiments, cilia were induced by culturing hTERT-RPE1 cells in DMEM/F12 with 0.5\% FBS for $48 \mathrm{~h}$ but without Cyto D to observe the pure effects of the following reagents without interference from Cyto D: brefeldin A (BFA; Sigma-Aldrich), 30N12 (ChemBridge), monensin (Sigma-Aldrich), cycloheximide (SigmaAldrich), GRASP siRNA, and Sar1(H79G). To suppress the expression of GRASP55, GRASP (GORASP2) siRNA (SMARTpool M-019045-01-0005; Thermo Scientific) was transfected into hTERT-RPE1cells stably expressing bP/rds-HA-FLAG using Lipofectamine RNAiMAX Transfection Reagent (Invitrogen) following the manufacturer's instructions. siGENOMEnontargeting siRNA pool \#1 (D-001206-13-05; Thermo Scientific) was used as a control siRNA. pClneo-Sar-Myc and pClneo-Sar1(H79G)-Myc were transfected into hTERT-RPE1cells stably expressing bP/rds-HAFLAG using Fugene 6 (Promega) following the manufacturer's instructions. pClneo-Sar1(H79G)-Myc carries one tyrosine to serine mutation at amino acid position 9 , which did not affect the dominant-negative property. To generate cell lines stably expressing $\mathrm{bP} / \mathrm{rds}$ or other genes, hTERTRPE1or IMCD3 cells were transfected with cDNAs using Fugene 6 following the manufacturer's instructions. Twenty-four hours later, medium was replaced with fresh growth medium containing selection reagent (puromycin for pMSCV vector). Selection medium was replaced every $3 \mathrm{~d}$ until colonies formed $18-21 \mathrm{~d}$ later.

Inhibition of conventional secretion and protein synthesis. After cilia induction by culturing in DMEM/F12 with $0.5 \%$ FBS for at least $48 \mathrm{~h}$, hTERT-RPE1 cells stably expressing bP/rds-HA-FLAG were treated with $0.5 \mu \mathrm{g} / \mathrm{ml}$ BFA, $0.5 \mu \mathrm{M} 30 \mathrm{~N} 12$, or $1 \mu \mathrm{M}$ monensin for $4 \mathrm{~h}$ before samples were prepared for Western blots or immunofluorescence microscopy. For fluorescence recovery after photobleaching (FRAP; see FRAP section below), hTERT-RPE1 cells stably expressing bP/rds-Dend2 or somatostatin receptor 3 (SSTR3)-GFP grown on glass-bottomed dishes were cultured in DMEM/F12 with $0.5 \%$ FBS for at least $48 \mathrm{~h}$ to induce cilia. For inhibition of conventional secretion, the cells were treated with $0.1 \mu \mathrm{g} / \mathrm{ml}$ BFA, $0.5 \mu \mathrm{M} 30 \mathrm{~N} 12,1 \mu \mathrm{M}$ monensin, or $150 \mu \mathrm{M}$ cycloheximide starting $0.5 \mathrm{~h}$ before photobleaching. Untreated cells were used for negative control experiments.

FRAP. FRAP experiments were performed with a method similar to those described previously (Boehlke et al., 2010; Trivedi et al., 2012) with modifications optimized for our microscope system as follows. Cells were incubated in the DMEM/F12 medium with $0.5 \%$ FBS in the presence and absence of inhibitors. Cells were maintained inside a sealed chamber (DMIRB/E ONICS-D35; Tokai Hit) that maintained the temperature $\left(37^{\circ} \mathrm{C}\right)$, humidity, and gas concentrations $\left(5 \% \mathrm{CO}_{2}\right.$ in $95 \%$ air $)$ on the microscope during the imaging procedures. FRAP was measured by a Leica TCS SP2 laser scanning confocal microscope using the FRAP module in Leica Confocal software version 2.61 Build 1537. To ensure the effective bleaching of $\sim 90 \%$ of the fluorescence signal, cilia were irradiated with an intense $488 \mathrm{~nm}$ laser. The laser power was set to $75 \%$, the pixel dwell time to $4.9 \mu \mathrm{s}$, and the pixel size to $0.092 \times 0.092 \mu \mathrm{m}$ using the confocal software. Images were acquired before, immediately after, and $1 \mathrm{~h}$ after bleaching using a $z$-series scan with a step size of 0.5 $\mu \mathrm{m}$. The imaging conditions did not cause significant photobleaching of fluorescent proteins. For qualitative assessment of cilia bleaching and recovery, maximum projection images were created for each condition. For quantitative assessment, single optical sections were analyzed using ImageJ software. Cilia fluorescence was quantified for prebleach and postbleach conditions and $1 \mathrm{~h}$ after photobleaching. The degrees of fluorescence recovery were normalized to prebleach fluorescence intensity after subtracting the measured background in the area with no objects. For BFA-treated cells, 50\% of cilia did not show any appreciable recovery; therefore, we quantified the FRAP data only for the $50 \%$ of cilia for which $\mathrm{P} / \mathrm{rds}$ recovered.

Cell surface biotinylation. Cell surface proteins were labeled by biotinylation as described previously (Tian et al., 2009) with minor revisions. Briefly, cells were incubated with EZ-Link Sulfo-NHS-SS-Biotin (Proteochem) in PBS buffer containing the following (in mM): $137 \mathrm{NaCl}, 10.1$ $\mathrm{Na}_{2} \mathrm{HPO}_{4}, 1.8 \mathrm{NaH}_{2} \mathrm{PO}_{4}$, pH 7.4, along with $100 \mu \mathrm{M} \mathrm{CaCl}$ and $1 \mathrm{mM}$ $\mathrm{MgCl}_{2}$, for $30 \mathrm{~min}$ at $4^{\circ} \mathrm{C}$ and the excess biotin was quenched by incubation with $100 \mathrm{~mm}$ glycine for $30 \mathrm{~min}$ at $4^{\circ} \mathrm{C}$. Cells were lysed in $1 \%$ Triton X-100 and the total lysate was fractioned to cell surface and cytoplasm parts by incubation with immobilized monomeric avidin agarose (Thermo Scientific) at $4^{\circ} \mathrm{C}$ overnight with end-over-end rotation. Loaded avidin beads were resuspended in $1 \times$ SDS-PAGE loading buffer.

Glycosylation analysis. Peptide- $\mathrm{N}$-Glycosidase F (PNGase F) and Endo $\mathrm{H}$ (New England Biolabs) treatments were done following the manufacturer's instructions. Briefly, $7 \mu$ l of protein sample was mixed with $1 \mu \mathrm{l}$ of G7 (for PNGase F) or G5 (for Endo H) reaction buffer, $1 \mu \mathrm{l}$ of $10 \times$ glycoprotein denaturing buffer, $1 \mu \mathrm{l}$ of 10\% Nonidet P-40 (for PNGase F), or $\mathrm{H}_{2} \mathrm{O}$ (for Endo $\mathrm{H}$ ), and $1 \mu \mathrm{l}$ of enzyme and the mixtures were incubated at $37^{\circ} \mathrm{C}$ for $1 \mathrm{~h}$.

Western blots. Cells or tadpole's eye balls were sonicated in PBS containing Complete Protease Inhibitor Mixture (Roche), assayed for total protein concentration, and then mixed with SDS sample buffer. The resulting samples were resolved by SDS-PAGE (12\% polyacrylamide) and transferred onto PVDF membranes. The following primary antibodies were used: mouse mAb anti-HA (Covance), mouse mAb anti-bP/rds 
(a kind gift from Dr. Brian Kevany, Department of Pharmacology, Case Western Reserve University, Cleveland, Ohio), mouse $\mathrm{mAb}$ anti-X. laevis $\mathrm{P} / \mathrm{rds}$ (Loewen et al., 2003; a kind gift from Dr. Robert S. Molday, The University of British Columbia, Vancouver, Canada), rabbit pAb antiGFP (Novus Biologicals), mouse mAb anti-ATPase $\mathrm{Na}^{+} / \mathrm{K}^{+} \alpha 5$ and mouse mAb anti- $\beta$-tubulin E7 (Developmental Studies Hybridoma Bank, University of Iowa, Iowa City, Iowa), mouse mAb anti-rhodopsin 1D4 (MacKenzie et al., 1984; the antibody originally generated by Dr. Robert S. Molday et al. was a kind gift from Dr. Vera Moiseenkova-Bell, Department of Pharmacology, Case Western Reserve University, Cleveland, $\mathrm{OH}$ ), rabbit pAb anti-GORASP2 (GRASP55; Proteintech), and rabbit $\mathrm{pAb}$ anti-Dend2 (custom made by us). The immunoreactive bands were detected using HyGLO Quick Spray Chemiluminescent HRP antibody detection reagents (Denville Scientific) according to the manufacturer's directions. Band intensities were analyzed with ImageJ.

Immunofluorescence microscopy. Cells were fixed in $4 \%$ paraformaldehyde for $30 \mathrm{~min}$ at room temperature. Tadpoles were anesthetized, decapitated, and their heads were fixed in $4 \%$ paraformaldehyde for $6 \mathrm{~h}$ at room temperature. Frozen heads were sectioned on a cryostat (CM1850; Leica) at $-20^{\circ} \mathrm{C}$. Fixed cells or eye sections were blocked in $1.5 \%$ normal goat serum diluted in PBS with v/v 0.1\% Triton X-100 (PBST) for $1 \mathrm{~h}$, incubated with primary antibody overnight at $4^{\circ} \mathrm{C}$, and then secondary antibody for $1 \mathrm{~h}$ at room temperature. The following primary antibodies were used: rat mAb anti-HA (Invitrogen), rabbit anti-mannosidase II antibody (Abcam), mouse mAb anti-acetylated tubulin (Sigma-Aldrich), mouse mAb anti-GM130 and mouse mAb anti-P230 (BD Biosciences). Goat anti-mouse Cy3, donkey anti-rabbit Cy3 (Jackson ImmunoResearch), and donkey anti-rat Alexa Fluor 488 (Invitrogen) were used as secondary antibodies. To visualize the outer segment (OS), tadpole sections were incubated with $10 \mu \mathrm{g} / \mathrm{ml}$ Alexa Fluor 633-conjugated wheat germ agglutinin (Invitrogen) overnight at room temperature in PBS with v/v $0.5 \%$ Triton X-100. Samples were visualized by confocal microscopy.

Generation of transgenic X. laevis. All animal experiments were performed in accordance with the Association for Research in Vision and Ophthalmology Statement for the Use of Animals in Ophthalmic and Vision Research based on the protocol approved by the institutional animal care and use committee at Case Western Reserve University.

Transgenic $X$. laevis expressing full-length or truncated $\mathrm{xP} / \mathrm{rds}$-Dend 2 were generated using the sperm nuclear injection method (Smith et al., 2006). Injected eggs were housed at $16^{\circ} \mathrm{C}$. Tadpoles of either sex were screened for the presence of green fluorescence in their eyes using a Leica MZ16F stereoscope when they were 7-10 d old and divided into three categories, "light," "medium," and "bright," according to the intensity of green fluorescence in their eyes. To ensure that the animals had similar expression levels, only the bright tadpoles (representing the top 39\% for each transgenic construct) were used for the experiments. Tadpoles were staged according to Nieuwkoop and Faber's normal table (Nieuwkoop and Faber, 1967).

Photoconversion of full-length or truncated $x \mathrm{P} / \mathrm{rds}$-Dend 2 fusion protein and retina preparation for confocal imaging. X. laevis transgenic tadpoles (10-14 d old, stage range of 41-46) raised in the dark were used for photoconversion at $\sim$ 10:00 A.M. The tadpoles were anesthetized with $0.026 \%$ tricaine (Sigma-Aldrich) and then placed in $6 \%$ methyl cellulose (Sigma-Aldrich). Photoconversion was performed by directing a $405 \mathrm{~nm}$ light source at their heads for 15-20 min with periodic breaks. For confocal imaging, tadpoles were killed immediately after photoconversion (10:00 A.M.), $4 \mathrm{~h}$ after photoconversion (2:00 P.M.), or $48 \mathrm{~h}$ after photoconversion (10:00 A.M.). Tadpoles were decapitated under anesthesia and retinas were dissected out and cultured in modified Wolf amphibian culture medium (55\% MEM; Invitrogen), 31\% Earle's sodium-free BBS ( $400 \mathrm{mg} / \mathrm{L} \mathrm{KCl}, 200 \mathrm{mg} / \mathrm{L} \mathrm{CaCl}_{2}, 100 \mathrm{mg} / \mathrm{L} \mathrm{MgSO}_{4}$, and $92 \mathrm{mg} / \mathrm{L}$ $\mathrm{NaH}_{2} \mathrm{PO}_{4} \cdot \mathrm{H}_{2} \mathrm{O}, 10 \%$ FBS, $30 \mathrm{~mm} \mathrm{NaHCO}_{3}, 700 \mathrm{mg} / \mathrm{L}$ D-glucose; Lodowski et al., 2013).

Confocal microscopy. Living retinas, fixed retinal sections, or fixed cells were imaged with a Leica TCS SP2 laser scanning confocal microscope. Leica Confocal Software Lite was used to construct maximum projection images from $Z$-stacks. All images used for statistical analysis were taken using the same laser power, zoom factor, image averaging, and resolution.
Image analysis, quantification, and statistics. To analyze the cilia localization of bP/rds-HA-FLAG in cells quantitatively, fixed cells were colabeled with rat anti-HA for bP/rds-HA-FLAG and mouse anti-acetylated tubulin for cilia. Based on the relative intensity of bP/rds-HA-FLAG in cilia compared with other regions of the cell, cells positive for both acetylated tubulin and HA were divided into three categories: cells with bP/ rds-HA-FLAG enriched in cilia were defined as strong; cells with bP/rdsHA-FLAG in cilia but with intensities lower than those of the other parts of the cell were defined as weak; and cells with no bP/rds-HA-FLAG in cilia were defined as NA. The percentage of each category was calculated by analyzing 100-1000 cells originated from at least three independent preparations.

To analyze the concentration of $\mathrm{xP} / \mathrm{rds}$ in photoreceptor cells, green fluorescence intensity of Dend2 that fused to full-length $\mathrm{xP} / \mathrm{rds}$ and CT truncations was quantified using ImageJ. Images were loaded and the shape tools were used to encompass an area of $15 \times 15$ pixel in both the OS and inner segment (IS) of photoreceptor cells. For IS, an area was selected inside the protein-dense region of $\mathrm{xP} / \mathrm{rds}_{1-316}$-Dend2, $\mathrm{xP} / \mathrm{rds}_{1-288}$-Dend2, and the corresponding relative region of $\mathrm{xP} / \mathrm{rds}$-Dend 2 . The concentration of fusion proteins was calculated by normalizing the measured intensity of Dend2 with the calibration curve of purified Dend2. The calibration curve of purified Dend2 was established as reported previously (Lodowski et al., 2013).

The Mann-Whitney rank sum test (MWRST) or the $t$ test (SigmaPlot 12.5; Systat Software) was used to determine whether the difference in the median values between two group samples was statistically significant. For some of the experiments, variability of the protein expression levels lead to a distortion of normal distribution. Therefore, a nonparametric statistic test, the MWRST, was used to determine significance in those pairwise comparisons.

Electron microscopy. Electron microscopy was performed as described previously (Lodowski et al., 2013). Briefly, hemisected tadpole heads were fixed in $4 \% \mathrm{w} / \mathrm{v}$ formaldehyde containing $0.1 \% \mathrm{w} / \mathrm{v}$ glutaraldehyde in $0.1 \mathrm{~m}$ HEPES buffer (Electron Microscopy Sciences) for $6 \mathrm{~h}$ at room temperature and then dehydrated in ethanol and embedded in LR White resin (Polysciences). Thin sections were blocked and incubated with antibody against Dend 2 for $12 \mathrm{~h}$ at $4^{\circ} \mathrm{C}$. Preimmune rabbit serum was used in place of the primary antibody for negative controls. After washing, samples were incubated for $1 \mathrm{~h}$ with $10 \mathrm{~nm}$ gold-conjugated goat antirabbit IgG (Ted Pella). The gold-labeled thin sections were examined by a JEOL 1200EX electron microscope.

\section{Results}

\section{$\mathrm{P} / \mathrm{rds}$ is not processed by Golgi mannosidase II}

To study the cilia targeting of $\mathrm{P} / \mathrm{rds}$, we transiently expressed full-length bovine P/rds, tagged with HA and FLAG antibody epitopes (abbreviated as bP/rds-HA-FLAG), in hTERT-RPE1 cells for which primary cilia are inducible (Fig. 1). Upon induction of primary cilia, bP/rds-HA-FLAG localized to cilia (Fig. $1 A$, $\mathrm{bP} / \mathrm{rds}-\mathrm{HA}-\mathrm{FLAG}$, green). The cilia localization was confirmed by a colocalization with acetylated tubulin (Fig. $1 A$, red). As a control, a well established cilia marker, SSTR3 (Berbari et al., 2008), was delivered to the cilia (Fig. $1 B$ ) under the same conditions. We confirmed that $\mathrm{bP} / \mathrm{rds}-\mathrm{HA}-\mathrm{FLAG}$ 's cilia localization is not dependent on the fusion tags. bP/rds fused to the fluorescent protein Dend2 localized to the primary cilia appropriately (Fig. $1 C)$. Furthermore, $\mathrm{bP} / \mathrm{rds}$ without any fusion tags localized to the primary cilia (Fig. 1D). SSTR3 was observed in both cilia and somatic plasma membranes, whereas $\mathrm{bP} / \mathrm{rds}$ was targeted to the primary cilia specifically and was barely observed in the somatic plasma membrane (a plasma membrane outside the primary cilia, defined in Hoffmeister et al., 2011). Therefore, the ciliatargeting mechanism of $\mathrm{P} / \mathrm{rds}$ appears to be more specific than that of SSTR3.

To understand the ER-Golgi-trafficking pathway of P/rds, we tested the glycosylation pattern of bP/rds expressed in hTERTRPE1 cells. The full-length $\mathrm{bP} / \mathrm{rds}$ acquired $N$-linked glycosyla- 

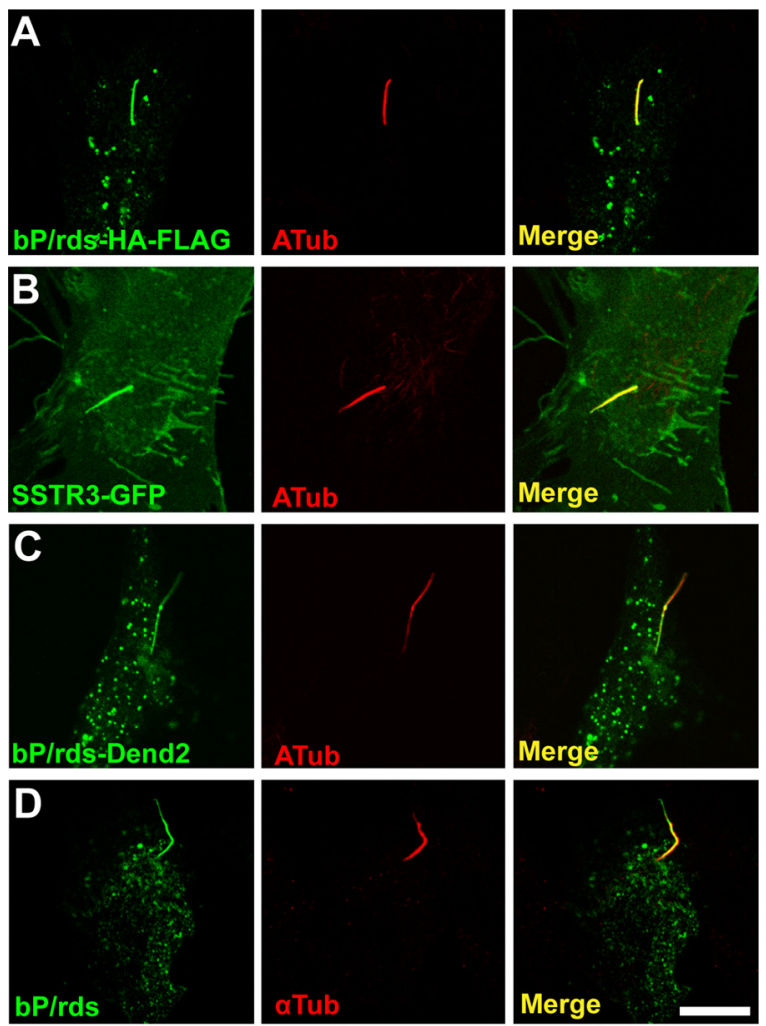

E
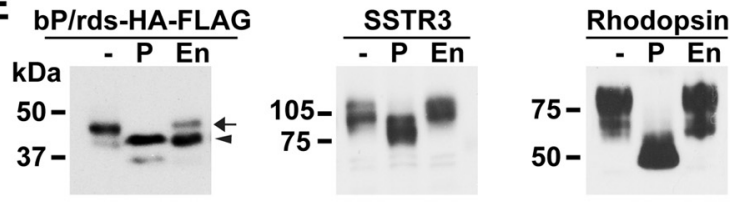

$\mathbf{F}$
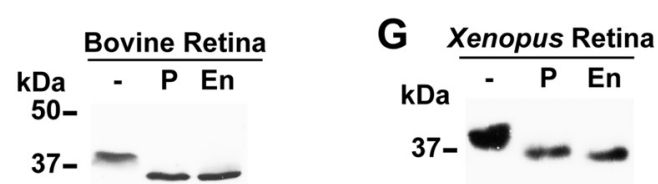

Figure 1. Cilia targeting of $\mathrm{P} / \mathrm{rds}$ in hTERT-RPE1 cells. $\boldsymbol{A}-\boldsymbol{D}, \mathrm{bP} / \mathrm{rds}$ with $\mathrm{HA}$ and FLAG tags $(\boldsymbol{A})$, SSTR3-GFP $(\boldsymbol{B})$, bP/rds-Dend2 ( $)$, or bP/rds ( ; green) colocalized with acetylated tubulin (ATub, red) or $\alpha$ tubulin ( $\alpha$ Tub, red) in the primary cilia of hTERT-RPE1 cells. $\boldsymbol{E}$, When expressed in hTERT-RPE1 cells, the majority bP/rds was Endo $\mathrm{H}$ (En] sensitive, whereas SSTR3 and rhodopsin were Endo $H$ resistant. $\boldsymbol{F}, \boldsymbol{G}$, Endogenous bovine $P / r d s ~(F$; detected by $m A b$ anti-bovine $\mathrm{P} / \mathrm{rds}$ ) and endogenous $X$. laevis $\mathrm{P} / \mathrm{rds}$ ( $\boldsymbol{G}$; detected by $\mathrm{mAb}$ anti-X. laevis $\mathrm{P} / \mathrm{rds}$ ) were sensitive to Endo $\mathrm{H}$ (En].P/rds, SSTR3, and rhodopsin were all sensitive to PNGase $F(P)$, confirming that they are glycoproteins. Arrow indicates the position of the Endo H-resistant form of P/rds; arrowhead indicates the position of EndoH-processed $\mathrm{P} / \mathrm{rds}$. The images are confocal images of a single $x-y$ plane. Scale bar, $10 \mu \mathrm{m}$.

tion in the ER, as demonstrated by its sensitivity to PNGase F (Fig. $1 E$, bP/rds-HA-FLAG, $\mathrm{P}$ ). However, we found that the majority of $\mathrm{bP} / \mathrm{rds}$ was not processed by GMII, as demonstrated by its robust sensitivity to Endo $\mathrm{H}$ (Fig. $1 E$, bP/rds-HA-FLAG, En, arrowhead). Consistently, $\mathrm{P} / \mathrm{rds}$ was sensitive to Endo $\mathrm{H}$ in bovine and $X$. laevis retinas (Fig. $1 F, G$ ). Unlike bP/rds, rhodopsin and SSTR3 expressed heterologously in hTERT-RPE1cells were processed by GMII and acquired resistance to Endo H (Fig. 1E, SSTR3 and rhodopsin). These observations led us to hypothesize that $\mathrm{P} / \mathrm{rds}$ was trafficked to the target cell membrane by an unconventional secretory pathway that bypasses at least the medialand trans-Golgi, where glycosylated proteins acquire resistance to Endo H (Rabouille et al., 1995).

\section{$\mathrm{P} / \mathrm{rds}$ is trafficked through an unconventional} trafficking route

To further investigate the trafficking pathway of $\mathrm{P} / \mathrm{rds}$, we established a stable hTERT-RPE1 cell line that expresses a relatively low level of bP/rds-HA-FLAG. In this cell line, the majority of $\mathrm{P} / \mathrm{rds}$ was Endo $\mathrm{H}$ sensitive (Fig. $2 A$, Con, $\mathrm{T}$, arrowhead). In the majority of the cells, $\mathrm{P} / \mathrm{rds}$ localized to the primary cilia. To clarify the role of the Golgi apparatus in the cilia targeting of $\mathrm{bP} / \mathrm{rds}$, we used small molecule inhibitors of Golgi-mediated trafficking. BFA inhibits conventional secretion and Golgi function by facilitating resorption of the Golgi to the ER (Scheel et al., 1997; Nebenführ et al., 2002). Consistent with this resorption, BFA facilitated redistribution and dispersion of the cis-Golgi marker GM130 throughout the cell (Fig. 2B). In the absence of BFA treatment, we noted that a small amount of $\mathrm{P} / \mathrm{rds}$ was Endo $\mathrm{H}$ resistant, although the majority was Endo $\mathrm{H}$ sensitive. However, this Endo $\mathrm{H}$-resistant $\mathrm{P} / \mathrm{rds}$ disappeared after BFA treatment (Fig. 2A, BFA). These results indicate that $\mathrm{P} / \mathrm{rds}$ became inaccessible to GMII. Conventional secretion of $\mathrm{P} / \mathrm{rds}$, if any existed, was blocked nearly completely. Under this condition, $\mathrm{P} / \mathrm{rds}$ was still maintained on the majority of the cilia (Fig. 2C), although an $\sim 10 \%$ reduction in the number of the $\mathrm{P} / \mathrm{rds}$-positive cilia was observed $(69.67 \pm 3.23 \%$ of the primary cilia were positive with $\mathrm{P} /$ rds-HA-FLAG in BFA treatment, 539 cilia from $n=3$ preparations, compared with $78.81 \pm 0.85 \%$ in untreated control, 448 cilia from $n=3$ preparations, mean $\pm \mathrm{SD}, p=0.018$ by $t$ test).

We then investigated whether $\mathrm{P} / \mathrm{rds}$ is actively trafficked to the cilia by a Golgi-independent mechanism. FRAP allowed us to test whether the delivery of new $\mathrm{P} / \mathrm{rds}$ can occur in the absence of the functional Golgi apparatus. To monitor the trafficking of $\mathrm{P} / \mathrm{rds}$ to the cilia of living cells, $\mathrm{P} / \mathrm{rds}$ was fused to the green fluorescent protein Dend2. After photobleaching of cilia-localized $\mathrm{bP} / \mathrm{rds}$ Dend2, $\sim 30 \%$ of the original level recovered within $1 \mathrm{~h}$ (Fig. $2 D$, E, P/rds-Dend2, Con), which closely coincides with the rate of degradation $(\sim 30 \% / \mathrm{h})$ measured after stopping the protein synthesis (Fig. $2 F$ ). When a similar experiment was conducted for cilia-localized SSTR3-GFP, $30 \%$ of the original level $(1 \mathrm{~h}-0 \mathrm{~h}$ ) recovered within $1 \mathrm{~h}$ (Fig. $2 \mathrm{D}, \mathrm{E}$, SSTR3-GFP, Con). To test the effect of BFA, cells were pretreated with BFA for a short time $(\sim 0.5 \mathrm{~h})$ before FRAP experiments. Because of the relatively slow replacement of proteins in the cilia (Fig. $2 D, E$ ), short-term BFA pretreatment $(\sim 0.5 \mathrm{~h})$ did not abolish SSTR3-GFP (Fig. $2 D$, SSTR3-GFP, BFA, Pre) or bP/rds-Dend2 (Fig. 2D, bP/rdsDend2, BFA, Pre) in the cilia. To evaluate whether newly synthesized proteins were capable of entering the cilia in the presence of BFA treatment, we photobleached the preexisting $\mathrm{bP} / \mathrm{rds}$-Dend2 or SSTR3-GFP in the cilia. After photobleaching of cilia-localized $\mathrm{bP} / \mathrm{rds}$-Dend2, $\sim 20 \%$ of the original level recovered within $1 \mathrm{~h}$ (Fig. $2 \mathrm{D}, \mathrm{E}, \mathrm{bP} / \mathrm{rds}$-Dend2, BFA). We assessed the FRAP for $1 \mathrm{~h}$, during which time the cilia structures were relatively intact. After $1 \mathrm{~h}$, BFA treatment caused gradual cilia resorption and shortening, which might have occurred due to compromised cilia trafficking of structural components. Approximately half of cilia did not show appreciable recovery of $\mathrm{P} / \mathrm{rds}$. After BFA treatment, there was a $20 \%$ reduction in the number of cells with cilia, indicating the effect of BFA on the retraction of cilia. Under the same conditions, the cilia trafficking of SSTR3, which is dependent on the Golgi apparatus, was completely blocked (Fig. 2D, E, SSTR3, BFA). Because BFA, which blocked Golgi function, did not completely block the cilia targeting of $\mathrm{P} / \mathrm{rds}$, these observations are supportive of unconventional trafficking of $\mathrm{P} / \mathrm{rds}$. However, because of the partial blockage of $\mathrm{P} / \mathrm{rds}$ trafficking in BFA-treated 

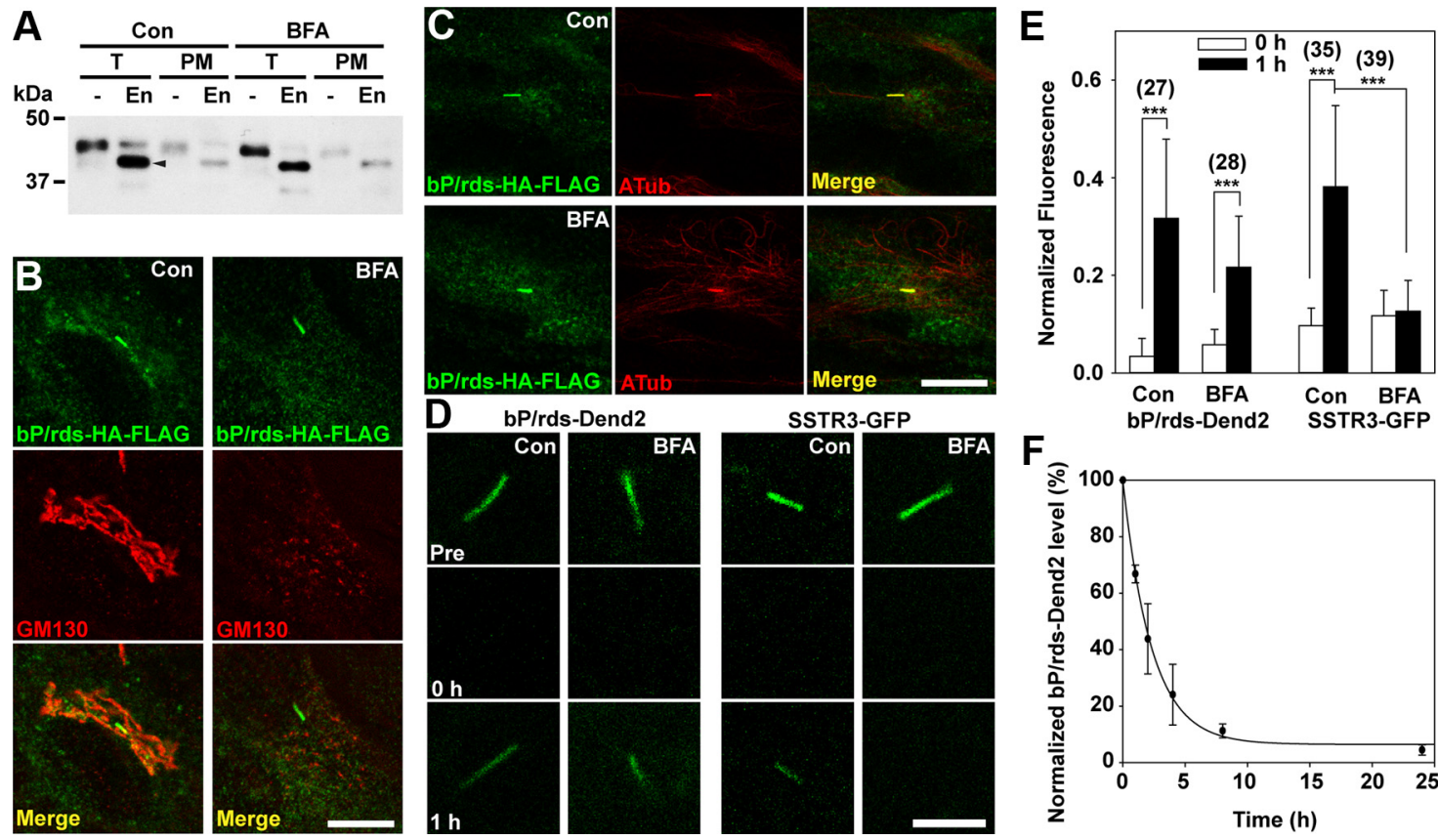

Figure 2. Brefeldin A causes resorption of cis-Golgi structure to ER, but does not abolish the cilia targeting of P/rds. A, Western blot analysis of BFA $(0.5 \mu \mathrm{g} / \mathrm{ml}$ for $4 \mathrm{~h})$-treated hTERT-RPE1 cells stably expressing bP/rds-HA-FLAG. Total cell lysate (T), and cell surface fraction (PM) isolated by biotinylation method were treated with Endo $\mathrm{H}$ (En). BFA treatment led to abolishment of the small amount of the Endo H-resistant form of P/rds on the cell surface. The arrowhead indicates the position of Endo H-processed P/rds. B, bP/rds (green) was colabeled with anti-GM130 (cis-Golgi, red) in the absence (Con) and presence (BFA) of BFA treatment. BFA treatment caused GM130 redistribution, which indicates the disruption of cis-Golgi structures. C, bP/rds (green) was colabeled with anti-acetylated tubulin (red) in the absence (Con) and presence (BFA) of BFA treatment. Cilia localization of bP/rds was maintained after BFA treatment. D, E, Trafficking of bP/rds-Dend2 or SSTR3, stably expressed in hTERT-RPE1 cells, was tested by FRAP in the absence (Con) and presence of (BFA) treatment. D, One hour after photobleaching, P/rds recovered in the cilia of control cells. P/rds recovered in $50 \%$ of cilia treated with BFA. Under the same conditions, SSTR3 recovery was blocked by BFA treatment. $\boldsymbol{E}$, The amounts of cilia localized P/rds and SSTR3 immediately following and $1 \mathrm{~h}$ after photobleaching. The amount was normalized to the prebleach levels. Significant recovery of bP/rds-Dend2, but no significant recovery of SSTR3, was observed in BFA-treated cells. ***p $<$ 0.001 by MWRST. The data are represented as mean \pm SD. The numbers of cilia analyzed from at least three sample preparations are indicated in parentheses. $F$, Cells stably expressing $\mathrm{bP} / \mathrm{rds}$-Dend2 were treated with $150 \mu \mathrm{m}$ cycloheximide for up to $24 \mathrm{~h}$ and then analyzed for the $\mathrm{bP} / \mathrm{rds}$-Dend2 protein level by Western blots. The half-life of $\mathrm{bP} / \mathrm{rds}$-Dend2 is estimated to be $\sim 1.8 \mathrm{~h}$. The images are confocal images of a single $x-y$ plane. Scale bars: $\boldsymbol{B}$ and $\boldsymbol{C}, 10 \mu \mathrm{m} ; \boldsymbol{D}, 5 \mu \mathrm{m}$.

cells, we could not exclude the partial involvement of the Golgi apparatus in the trafficking of $\mathrm{P} / \mathrm{rds}$.

To further define the route of $\mathrm{P} / \mathrm{rds}$ trafficking to the cilia, we tested the effects of $30 \mathrm{~N} 12$, a small molecule screened by a chemical genetic approach that inhibits trans-Golgi to plasma membrane trafficking (Nieland et al., 2004). Unlike BFA, 30N12 does not disrupt ER to Golgi trafficking. Similar to its response after BFA treatment, Endo H-resistant P/rds, which was faintly visible, became hardly detectable after $30 \mathrm{~N} 12$ treatment (the percentage of the Endo $\mathrm{H}$ resistant form of bP/rds-HA-FLAG dropped from $9.16 \pm 1.07 \%$ in control cells to $1.30 \pm 0.62 \%$ in $30 \mathrm{~N} 12$-treated cells, mean $\pm \mathrm{SD}, p<0.001$ by $t$ test, $n=3$ preparations; Fig. $3 A$ ). However, the population of $\mathrm{P} /$ rds-positive cilia was unaffected by $30 \mathrm{~N} 12(78.19 \pm 0.75 \%$ of the primary cilia were positive with $\mathrm{bP} /$ rds-HA-FLAG in $30 \mathrm{~N} 12$ treatment, 615 cilia from $n=3$ preparations, compared with $79.85 \pm 2.75 \%$ in control, 529 cilia from $n=3$ preparations, mean $\pm \mathrm{SD}, p=0.456$ by $t$ test; Fig. $3 B$ ). Despite the trans-Golgi-mediated trafficking being inhibited, $\mathrm{P} / \mathrm{rds}$ was actively trafficked to the cilia, as assessed by FRAP analysis. One hour after photobleaching, recovery of $\mathrm{bP} / \mathrm{rds}-$ Dend2 to $23.3 \%$ of the original level (Fig. 3C,D) was observed on average and all tested cilia showed recovery of bP/rds-Dend2. This degree of recovery in the presence of $30 \mathrm{~N} 12$ was not significantly different from that observed in the absence of $30 \mathrm{~N} 12(p=$ 0.054 by MWRST). This rate of recovery closely coincides with the stability of bP/rds-Dend 2 (Fig. $2 F$ ), and thus suggests that the ciliary $\mathrm{P} / \mathrm{rds}$ was maintained by active trafficking and decomposition of $\mathrm{P} / \mathrm{rds}$. We also confirmed that the recovery of $\mathrm{P} / \mathrm{rds}$ requires the new synthesis of $\mathrm{P} / \mathrm{rds}$, because $\mathrm{bP} /$ rds-Dend 2 trafficking was significantly inhibited after treatment with cycloheximide (Fig. 3C, D, CYH), which effectively blocked bP/rds-Dend2 synthesis (Fig. 2F). In the presence of 30N12, SSTR3-GFP did not recover in any of the cilia tested, indicating that conventional secretion was effectively blocked (Fig. 3C,D, SSTR3-GFP). 30N12 is a relatively new inhibitor of trans-Golgi to plasma membrane trafficking. More traditionally, monensin, an antibiotic, has been used to inhibit the Golgi-mediated trafficking events, especially at the late compartments of Golgi (Mollenhauer et al., 1990). We found that monensin significantly inhibited the cilia targeting of SSTR3, whereas it allowed the cilia targeting of $\mathrm{P} / \mathrm{rds}$ in a manner similar to $30 \mathrm{~N} 12$ (Fig. 3B-D). These experiments using BFA, $30 \mathrm{~N} 12$, and monensin indicate that the conventional secretion from the TGN is not essential for $\mathrm{P} / \mathrm{rds}$ trafficking. Therefore, $\mathrm{P} / \mathrm{rds}$ is trafficked by an unconventional secretion mechanism.

\section{Unconventional trafficking pathway of $\mathrm{P} / \mathrm{rds}$ is distinct from} the previously described GRASP55-dependent route

Many membrane proteins use COPII-coated vesicles to exit the ER after their synthesis. We investigated whether the unconventional trafficking of $\mathrm{P} / \mathrm{rds}$ is dependent on COPII. COPII assembly is mediated by Sarl GTPase (Kuehn et al., 1998). We disrupted this assembly process by expressing the dominantnegative Sar1(H79G) (Aridor et al., 1995). The expression of Sar1(H79G) led to redistribution of Golgi apparatus, as indicated by dispersion of a cis-Golgi marker, GRASP55 (Fig. 4A, top). Because COPII-coated vesicles are essential for the maintenance 


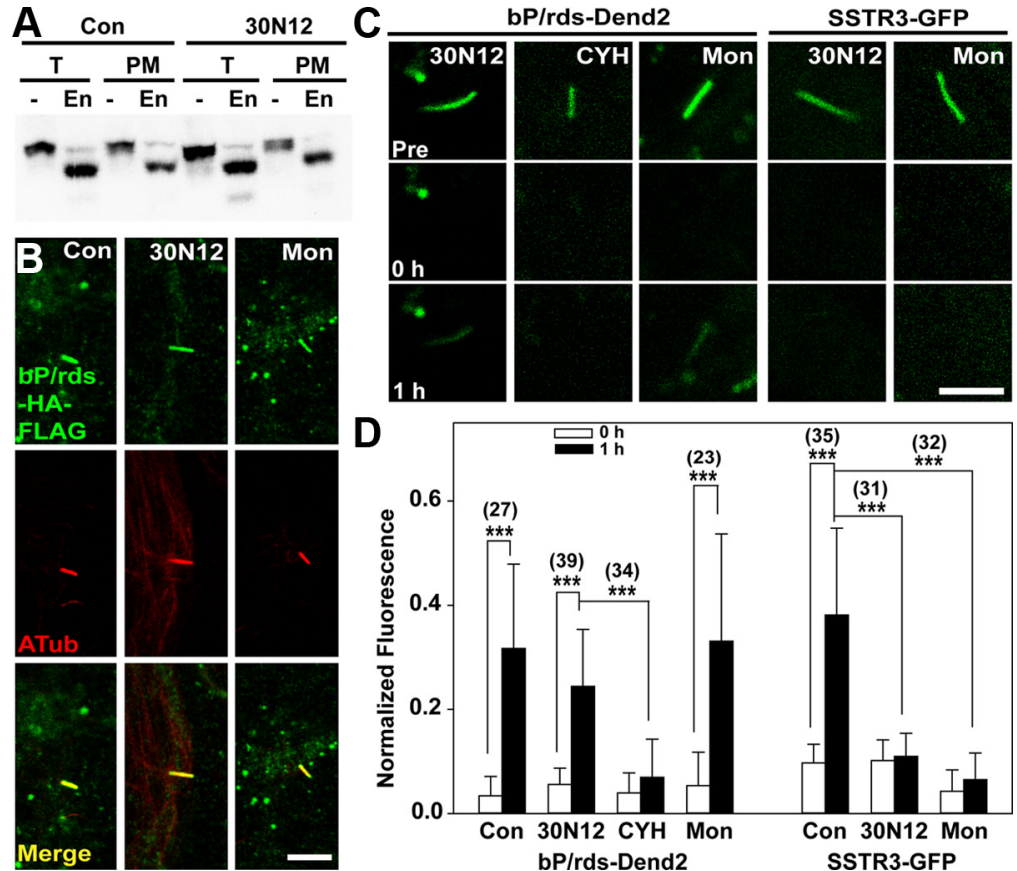

Figure 3. Trans-Golgi exit is not essential for cilia targeting of P/rds. $A, B$, hTERT-RPE1 cells stably expressing $\mathrm{bP} / \mathrm{rds}-\mathrm{HA}$-FLAG were treated with $0.5 \mu \mathrm{m} 30 \mathrm{~N} 12$ or $1 \mu \mathrm{m}$ monensin, which block the function of trans-Golgi structures, for $4 \mathrm{~h}$. $A$, The samples treated with 30N12 were analyzed by Western blots. Total lysate (T) and cell surface fraction (PM) were also treated with Endo $\mathrm{H}$ (En). After 30N12 treatment, the small amount of the Endo $\mathrm{H}$-resistant form of $\mathrm{P} / \mathrm{rds}$ on $\mathrm{PM}$ became nearly undetectable. $\boldsymbol{B}, \mathrm{bP} / \mathrm{rds}$ (green) was colabeled with anti-acetylated tubulin (red) with (30N12, Mon) or without (Con) treatment. Cilia localization of bP/rds was maintained after 30N12 or monensin treatment. C, D, The trafficking of bP/rds-Dend2 or SSTR3-GFP, stably expressed in hTERT-RPE1 cells, was tested by FRAP in the absence of (Con) and presence of 30N12 (30N12) or monensin (Mon). The effect of cycloheximide (CYH) treatment was also tested on the trafficking of bP/rds-Dend2. C, One hour after photobleaching, P/rds recovered in the cilia of 30N12- or monensin-treated cells. Under the same conditions, SSTR3 recovery was blocked by 30N12 or monensin treatment. $\mathrm{P} / \mathrm{rds}$ recovery was blocked by $\mathrm{CYH}$ treatment, suggesting that protein synthesis is required for $\mathrm{P} / \mathrm{rds}$ recovery in cilia. $\boldsymbol{D}$, The amounts of cilia-localized P/rds and SSTR3 immediately following and $1 \mathrm{~h}$ after photobleaching. The amount was normalized to the prebleach levels. Significant recovery of bP/rds-Dend2 was observed in 30N12- or monensin-treated cells, but not in CYH-treated cells. SSTR3 recovered in untreated control cells; however, the recovery was blocked by 30N12 or monensin. Therefore, 30N12 and monensin blocks the conventional trafficking of SSTR3 effectively, but does not block the unconventional trafficking of $\mathrm{P} / \mathrm{rds}$. The data are represented as mean $\pm \mathrm{SD}$. ${ }^{* * *} p<0.001$ by MWRST. The numbers of cilia analyzed from at least three sample preparations are indicated in parentheses. The images are confocal images of a single $x-y$ plane. Scale bars, $5 \mu \mathrm{m}$.

of Golgi apparatus, this result indicates that COPII-mediated trafficking was effectively blocked by Sar1(H79G). A similar effect was observed when cells were treated with BFA (Fig. 2B), which blocks COPI-mediated trafficking. As a control, the expression of wild-type Sar1 did not affect the structure of the Golgi apparatus (Fig. 4A, bottom). The expression of Sar1(H79G) led to a dramatic decline in the number of cilia positive for $\mathrm{bP} / \mathrm{rds}$ (20.01 $\pm 2.67 \%$ of the primary cilia were positive with $\mathrm{bP} / \mathrm{rds}$ HA-FLAG in the cells expressing Sar1(H79G), 205 cilia from $n=$ 3 preparations, compared with $80.75 \pm 1.02 \%$ in the cells expressing Sar 1, 155 cilia from $n=3$ preparations, mean \pm SD, $p<$ 0.001 by $t$ test; Fig. $4 B$ ). Because the exit from the ER was blocked, $\mathrm{P} / \mathrm{rds}$ accumulated in the ER (Fig. $4 C$ ). Therefore, this experiment indicates that the cilia targeting of $\mathrm{P} / \mathrm{rds}$ is dependent on the COPII-coated vesicles that bud off from the ER.

Some of the unconventional trafficking pathways are dependent on GRASP55, a protein mainly localized to the cis-Golgi apparatus (Gee et al., 2011; Giuliani et al., 2011). We tested the effect of knocking down GRASP55 by siRNA, a treatment known to effectively block GRASP-dependent unconventional secretion (Gee et al., 2011). After siRNA knock-down, the protein expression of GRASP55 was suppressed to $6.48 \pm 0.06 \%$ (mean \pm SD) of the original level (Fig. $4 D$ ). This knock-down did not affect the cilia targeting of P/rds (75.61 \pm
$3.21 \%$ of the primary cilia were positive with bP/rds-HA-FLAG in GRASP55 siRNAtransfected cells, 489 cilia from $n=3$ preparations compared with $77.76 \pm 1.72 \%$ in nontargeting siRNA-transfected cells, 439 cilia from $n=3$ preparations, mean $\pm \mathrm{SD}$, $p=0.45$ by $t$ test; Fig. $4 E$ ). Therefore, unconventional trafficking of $\mathrm{P} / \mathrm{rds}$ is not dependent on GRASP55.

\section{C-terminal tail of $\mathrm{P} /$ rds supports cilia targeting and enrichment}

To understand the regions supporting the specific cilia targeting of $\mathrm{P} / \mathrm{rds}$, the CT tail region was dissected. For this dissection, the full-length and truncated $\mathrm{P} / \mathrm{rds}$ were transiently expressed because transient expression allowed us to test the localizations of different constructs at various expression levels. The full-length $\mathrm{bP} / \mathrm{rds}$ localized to $\sim 90 \%$ of acetylated tubulinpositive cilia (Fig. 5A, bP/rds-HA-FLAG, strong + weak). Among these positive cilia, the majority of them were highly concentrated with $\mathrm{bP} / \mathrm{rds}$ (Fig. $5 A, \mathrm{bP} /$ rds-HA-FLAG, strong). The CT tail region of $\mathrm{P} / \mathrm{rds}$ is highly homologous among species (Fig. 5B) and constitutes the largest domain exposed to the cytoplasmic side. The truncation mutant bP/ $\mathrm{rds}_{1-342}$ localized to cilia similarly to $\mathrm{bP} /$ rds (Fig. 5A, C, bP/rds ${ }_{1-342}$-HA-FLAG), indicating that the last four amino acids of $\mathrm{P} / \mathrm{rds}$ were dispensable for cilia localization. Truncation of an additional six amino acids ( $\left.\mathrm{bP} / \mathrm{rds}_{1-336}\right)$ led to a compromised localization of $\mathrm{P} / \mathrm{rds}$ in cilia. $\mathrm{bP} /$ $\mathrm{rds}_{1-336}$ localized to $70 \%$ of acetylated tubulin-positive cilia (Fig. $5 \mathrm{~A}, \mathrm{C}, \mathrm{bP} / \mathrm{rds}_{1-}$ 336 -HA-FLAG, strong + weak), a $20 \%$ decline compared with the cells expressing $\mathrm{bP} / \mathrm{rds}$. The amount of $\mathrm{bP} / \mathrm{rds}_{1-336}$ present was also reduced in the majority of cilia (Fig. $5 A, \mathrm{bP} / \mathrm{rds}_{1-336}-\mathrm{HA}-\mathrm{FLAG}$, weak and NA). Therefore, these results suggest that the six amino acids (EDAGQA) from 337 to 342 aa facilitate the passing of $\mathrm{bP} / \mathrm{rds}$ through the transition zone and concentrating it to the primary cilia. However, because $\mathrm{bP} / \mathrm{rds}_{1-336}$ still localized to the majority of cilia, the cilia localization of $\mathrm{P} / \mathrm{rds}$ is contributed by another region. Further truncation of six amino acids $\left(\mathrm{bP} / \mathrm{rds}_{1-330}\right.$ ) led to total abolishment of cilia targeting (Fig. $5 \mathrm{~A}, \mathrm{C}$, $\mathrm{bP} / \mathrm{rds}_{1-330}$-HA-FLAG). These results indicate that the region spanning 331-342 aa contains the sequence necessary for cilia targeting and enrichment. Gradual compromise of the cilia localization suggests a modular nature of the cilia localization signals. The region within aa 337-342 is required for enrichment to the cilia and the collective regions at aa 331-342 are essential for cilia targeting.

\section{Unconventional secretion prevents $\mathrm{P} / \mathrm{rds}$ access to GMII}

Although expressed in a stable fashion, some variation was observed in terms of the expression levels of $\mathrm{P} / \mathrm{rds}$ in hTERT-RPE1 cells. In cells expressing at low levels, full-length $\mathrm{bP} / \mathrm{rds}$ localized primarily to the cilia (Fig. $6 A-C$, bP/rds-HA-FLAG [low], 6D, $\mathrm{bP} / \mathrm{rds}-\mathrm{HA}-\mathrm{FLAG}$, arrow). However, in cells with overexpression, full-length $\mathrm{bP} / \mathrm{rds}$ also localized to intracellular membra- 

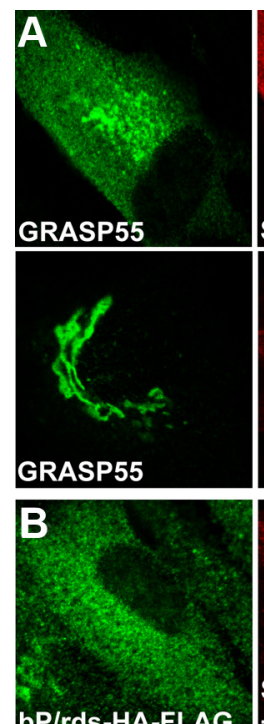

bP/rds-HA-FLAG

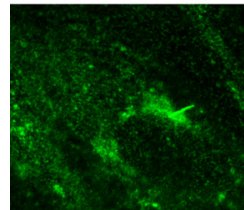

bP/rds-HA-FLAG

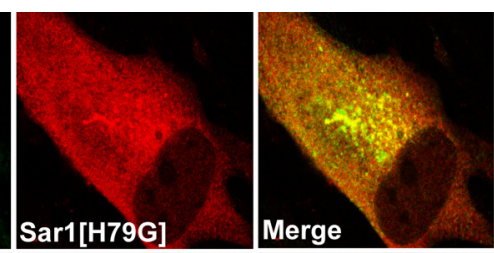

Merge
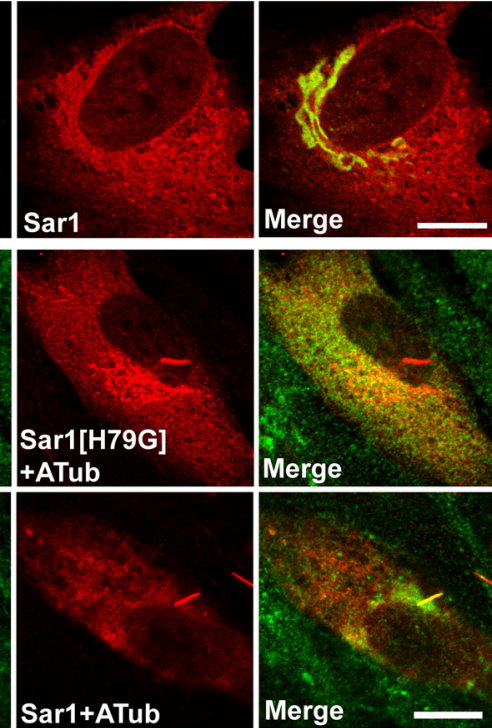
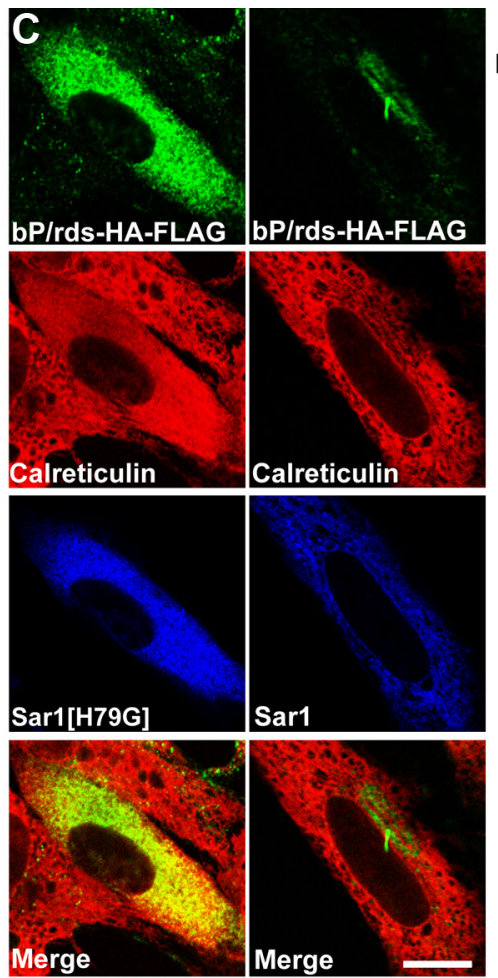

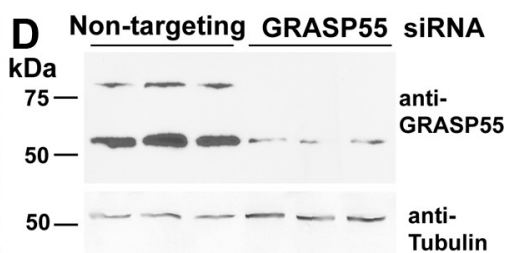

Figure 4. Cilia targeting of P/rds in cilia is dependent on COPII, but not on the GRASP55-mediated mechanism. $A$, Cells stably expressing bP/rds that are also transiently expressing either wild-type or the H79G mutant of Sar1 (red) were colabeled with anti-GRASP55 (green). Expression of Sar1(H79G), but not wild-type Sar1, caused the disruption of cis-Golgi structure. B, P/rds (green) was colabeled with wild-type or the H79G mutant of Sar1 (red). The primary cilia is also labeled by anti-acetylated tubulin (red, the same color as Sar1). Cilia targeting of P/rds was inhibited by Sar1(H79G). C, P/rds (green) was colabeled for Sar1 (blue) and calreticulin (red, an ER marker). P/rds localized in ER in the cell expressing Sar1(H79G). D, E, Cells stably expressing bP/rds were transfected with GRASP55 siRNA and then analyzed for GRASP55 protein level ( $\boldsymbol{D}$ ) and the localization of P/rds ( $\boldsymbol{E}$; green) in primary cilia (acetylated tubulin, red). The siRNA effectively reduced the protein expression of GRASP55 by more than 10 -fold, but did not affect the cilia targeting of P/rds. The images are confocal images of a single $x-y$ plane. Scale bars, $10 \mu m$.

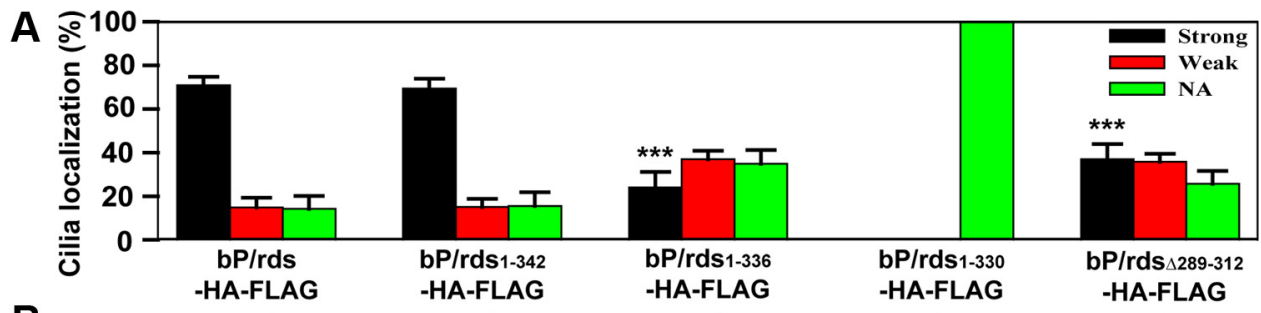

B

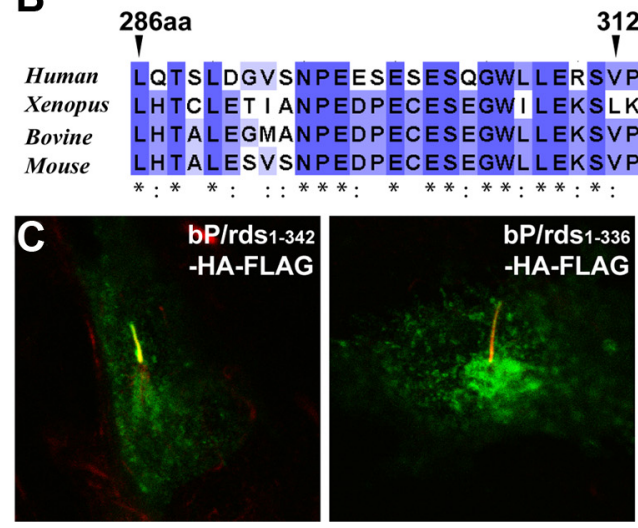

312aa 317aa

326aa 330aa 336aa 342aa

$342 a a$

Xenopus

Bovine LHTALEGMANPEDPECESEGWLLEKSVPETWKAFLESVKKLGKGNQVEAEG - EDAGQAPAAG

Mouse LHTALESVSNPEDPECESEGWLLEKSVPETWKAFLESFKKLGKSNQVEAEG-ADAGPAPEAG
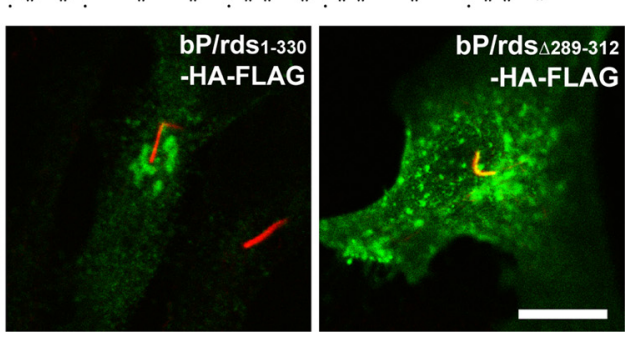

Figure 5. The C-terminal tail region of P/rds is essential for the cilia targeting. $A$, hTERT-RPE1 cells transiently expressing full-length or CT-truncated bP/rds were analyzed for the percentage of the primary cilia positive to $\mathrm{P} / \mathrm{rds}$. Strong (black bar), $\mathrm{bP} / \mathrm{rds}$ is enriched in cilia; weak (red bar), bP/rds is in cilia but not enriched; $\mathrm{NA}$ ( $\mathrm{green}$ bar), $\mathrm{P} / \mathrm{rds}$ is not observed in cilia. ${ }^{* * *} p<0.001$ compared with $\mathrm{bP} / \mathrm{rds}$ by $t$ test. Error bars represent SD. bP/rds (1060 cilia from $n=6$ preparations), $\mathrm{bP} / \mathrm{rds}_{1-342}$ ( 635 cilia from $n=3$ preparations), bP/rds 1-336 (416 cilia from $n=3$ preparations), $\mathrm{bP} / \mathrm{rds} \mathrm{s}_{1-330}$ (245 cilia from $n=3$ preparations), $b P / \mathrm{rds}_{\Delta 289-312}$ (501 cilia from $n=3$ preparations). A gradual reduction in the cilia-targeting efficacy was observed by $(T$ truncations. $\boldsymbol{B}$, The alignment of the

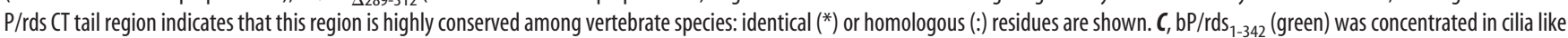
full-length protein. bP/rds $s_{1-336}$ (green) and bP/rds ${ }_{\Delta 289-312}$ (green) localized in cilia but were not enriched and bP/rds $s_{1-330}$ (green) did not localize in cilia. Acetylated tubulin (red) was used as a cilia marker. The images are confocal images of a single $x-y$ plane. Scale bar, $10 \mu \mathrm{m}$. 

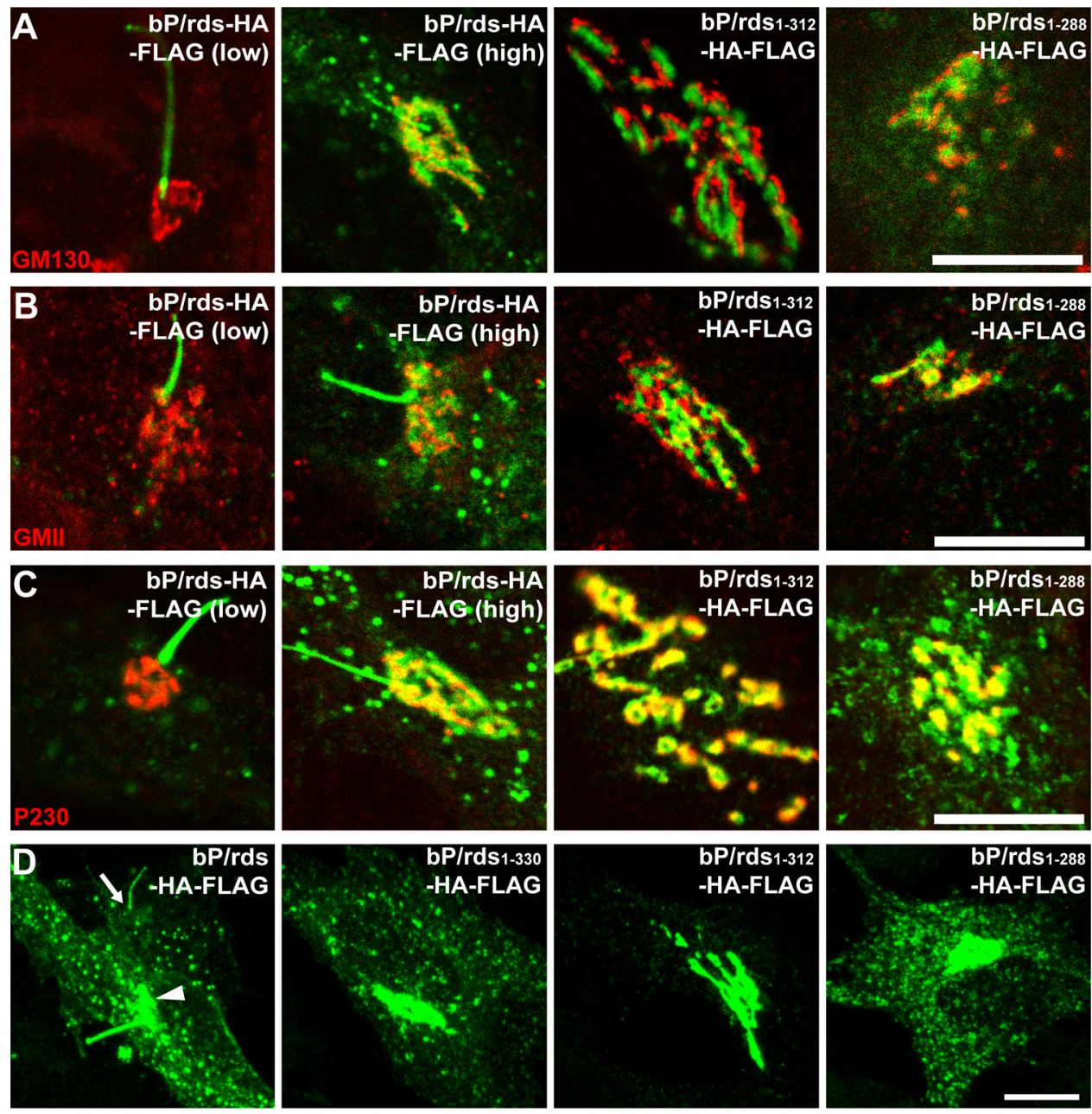

E bP/rds1-342 $\mathrm{bP} / \mathrm{rds} 1-336 \quad \mathrm{bP} / \mathrm{rds} 1-330 \quad \mathrm{bP} / \mathrm{rds} 1-326 \quad \mathrm{bP} / \mathrm{rds} 1-316 \quad \mathrm{bP} / \mathrm{rds} 1-312 \quad \mathrm{bP} / \mathrm{rds} 1-288 \mathrm{bP} / \mathrm{rds} \triangle 289-312$

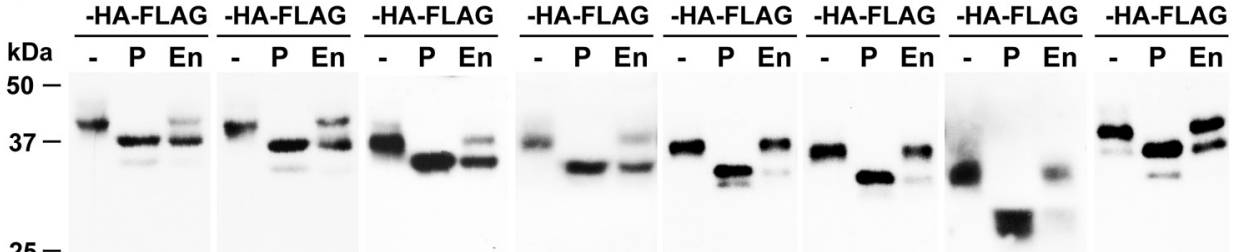

$25-$

Figure 6. C-terminal tail region of P/rds is essential for Golgi retention. $\boldsymbol{A}-\mathrm{C}$, hTERT-RPE1 cells transiently expressing full-length or CT-truncated bP/rds (green) were colabeled for GM130 ( $\boldsymbol{A}$; cis-Golgi), for GMII ( $\boldsymbol{B}$; medial and trans-Golgi), or for P230 (C; TGN). The images are confocal images of a single $x-y$ plane. $\boldsymbol{D}$, Maximum projection images of bP/rds and $(\mathrm{CT}$ truncations. bP/rds is concentrated in cilia when the expression level is low (arrow) and localized to Golgi and other parts of cells except cilia when the expression level is high (arrowhead). CT truncation, down to the position 312, led to the accumulation of P/rds in the Golgi apparatus. Further truncation to position 288 led to exit of P/rds from the Golgi. Scale bars, $10 \mu \mathrm{m}$. E, CT-truncated bP/rds transiently expressed in hTERT-RPE1cells were treated with PNGase F (P) or Endo H (En). Truncation of the CT tail led to acquisition of Endo $\mathrm{H}$ resistance. Therefore, P/rds is capable of serving as a substrate for the GMII.

nous structures (Fig. 6A-C, bP/rds-HA-FLAG [high], 6D, bP/ rds-HA-FLAG, arrowhead). Truncation of the CT region from position 327-346 aa, which is essential for the cilia targeting, minimally affected the Endo $\mathrm{H}$ sensitivity of P/rds (Fig. 6E, bP/ $\mathrm{rds}_{1-342}$-HA-FLAG, bP/rds $\mathrm{ra3}_{1-336}$-HA-FLAG,bP/rds $\mathrm{r}_{1-330}$-HA-FLAG, and $\mathrm{bP} / \mathrm{rds}_{1-326}$-HA-FLAG). Because of the loss of the region essential for cilia targeting, $\mathrm{bP} / \mathrm{rds}_{1-330}$ did not localize to the cilia and its intracellular localization was otherwise similar to that of the fulllength $\mathrm{P} / \mathrm{rds}$ (Fig. $6 \mathrm{D}, \mathrm{bP} / \mathrm{rds}_{1-330}$-HA-FLAG). In cells with overexpression, full-length $\mathrm{bP} / \mathrm{rds}$ was also observed to partially localize to Golgi apparatus, as demonstrated by colocalization with the TGN marker P230, the cis-Golgi marker GM130, and the mid- and transGolgi marker GMII (Fig. 6A-C, bP/rds-HA-FLAG [high]). This par- tial colocalization could explain why a small fraction of $\mathrm{bP} / \mathrm{rds}$ acquired Endo H resistance. However, in cells with optimum expression levels, $\mathrm{bP} / \mathrm{rds}$ was able to localize to the cilia without appreciable localization to the Golgi apparatus, as demonstrated by poor colocalization with P230, GM130, and GMII (Fig. 6A-C, bP/rds-HAFLAG, low).

We found that further truncation of regions $317-330$ or 313330 aa from $\mathrm{P} / \mathrm{rds}_{1-330}$ resulted in a dramatic increase in Endo $\mathrm{H}$ resistance (Fig. $6 \mathrm{E}, \mathrm{bP} / \mathrm{rds}_{1-316}$-HA-FLAG and $\mathrm{bP} / \mathrm{rds}_{1-312}$-HAFLAG). Unlike $\mathrm{bP} / \mathrm{rds}, \mathrm{bP} / \mathrm{rds}_{1-312}$ localized predominantly to the Golgi apparatus (Fig. $6 A-C$, bP/rds $1-312$-HA-FLAG) in all cells tested. Within the Golgi, bP/rds ${ }_{1-312}$ was confined to the late Golgi compartments (Fig. $6 \mathrm{~A}-\mathrm{C}$, bP/rds $\mathrm{rs}_{1-32}$-HA-FLAG), as 


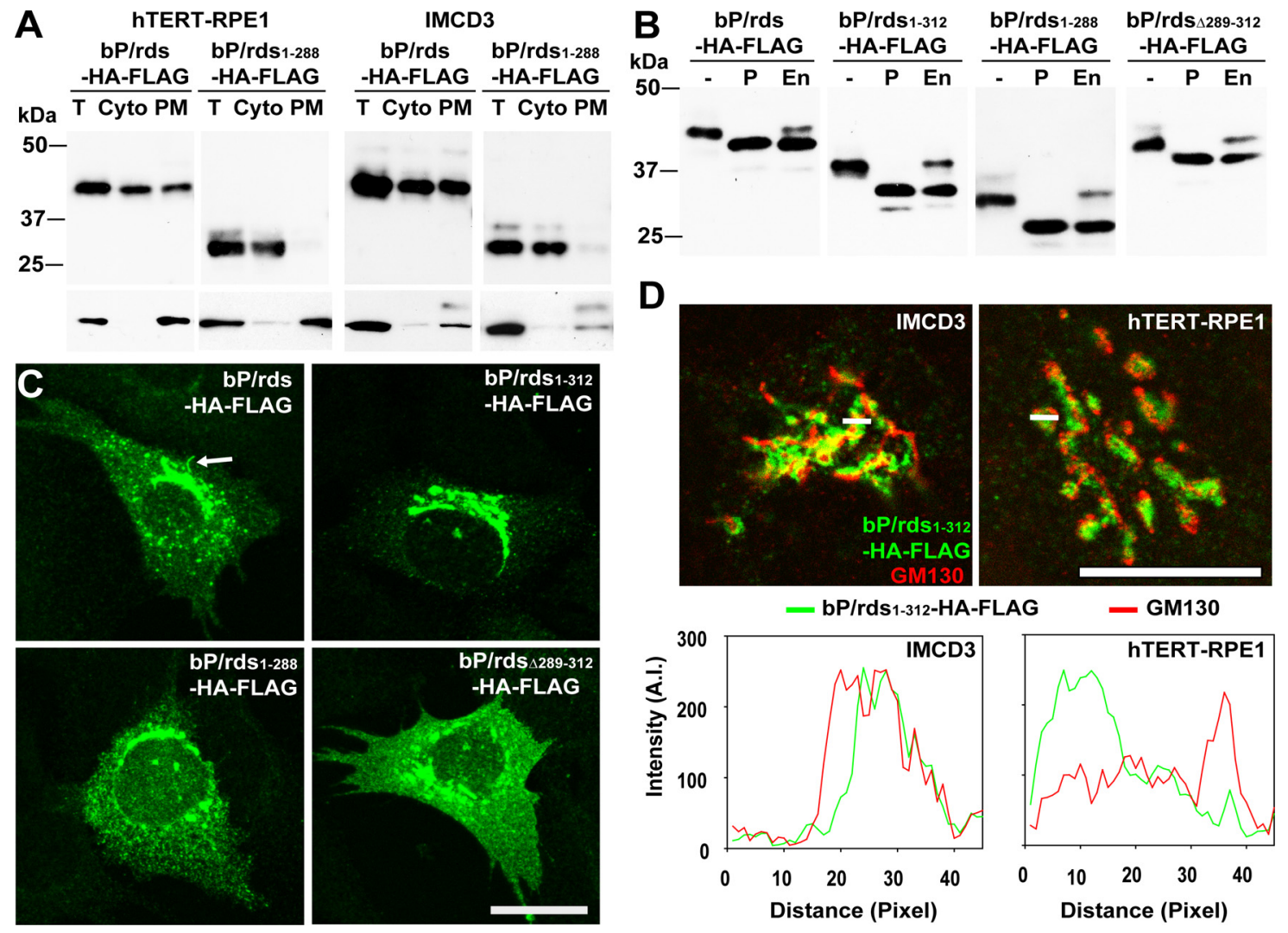

Figure 7. Unconventional cilia targeting of P/rds in IMCD3 cells. A, hTERT-RPE1and IMCD3 cells stably expressing bP/rds or bP/rds $1-288$ were separated into cytoplasm (Cyto) and plasma membrane (PM) fractions by the biotinylation method and analyzed by Western blots. bP/rds ${ }_{1-288}$ is barely observed in the plasma membrane. Na ${ }^{+} / \mathrm{K}^{+}$ATPase (bottom) was used to demonstrate that the plasma membrane proteins were pulled down effectively. $\boldsymbol{B}$, PNGase $\mathrm{F}(\mathrm{P})$ and Endo $\mathrm{H}$ (En) treatments of IMCD3 cells stably expressing bP/rds or its truncation mutants. $\boldsymbol{C}$, Maximum projection images of full-length and (T-truncated bP/rds expressed in IMCD3 (green). The arrow indicates the cilium. D, Top, IMCD3 and hTERT-RPE1 cells stably expressing bP/rds 1-312 $_{2}$ (HA, green) were labeled for a cis-Golgi marker GM130 (red). Bottom, Intensity of bP/rds $s_{1-312}$ and GM130 (arbitrary intensity units, Al) along the white bars shown in the top. Significant overlap between $\mathrm{bP} / \mathrm{rds}_{1-312}$ and cis-Golgi was observed in IMCD3 cells, whereas the overlap is less significant in hTERT-RPE1 cells. Scale bars, $10 \mu \mathrm{m}$.

demonstrated by colocalization with the TGN marker P230 and poor colocalization with the cis-Golgi marker GM130 and the midand trans-Golgi marker GMII. The confinement of bP/ $/ \mathrm{rds}_{1-312}$ to the late Golgi compartments suggests that the majority of $\mathrm{bP} / \mathrm{rds}_{1-312}$ passed through the medial- to trans-Golgi apparatus, where Endo $\mathrm{H}$ resistance was acquired by GMII. Therefore, P/rds can serve biochemically as a substrate for GMII, which confers Endo H resistance. However, a unique unconventional trafficking route made the majority of bP/rds inaccessible to GMII.

\section{CT tail contains a region required for Golgi retention}

Considering the unique localization of $\mathrm{bP} / \mathrm{rds}_{1-312}$ to the Golgi apparatus (Fig. $6 A-D, \mathrm{bP} / \mathrm{rds}_{1-312}-\mathrm{HA}-\mathrm{FLAG}$ ), we assumed that $\mathrm{P} / \mathrm{rds}$ contains the information leading to the Golgi retention in its primary sequence. To test this assumption, the well conserved $\mathrm{CT}$ region of $\mathrm{bP} / \mathrm{rds}$ (Fig. $5 \mathrm{~B}$ ) was further truncated to generate $\mathrm{bP} / \mathrm{rds}_{1-288}$. We found that $\mathrm{bP} / \mathrm{rds}_{1-288}$ was observed outside of the Golgi apparatus (Fig. $6 A-D$, bP/rds $1_{1-288}-\mathrm{HA}-\mathrm{FLAG}$ ), unlike $\mathrm{bP} / \mathrm{rds}_{1-312}$, which was confined to the Golgi apparatus (Fig. $6 A-D, \mathrm{bP} / \mathrm{rds}_{1-312}$-HA-FLAG). The majority of $\mathrm{bP} / \mathrm{rds}_{1-288}$ was Endo $\mathrm{H}$ resistant (Fig. $6 E$, bP/rds ${ }_{1-288}$-HA-FLAG) and therefore processed by the Golgi resident enzyme GMII. Therefore, the removal of 289-312 aa allowed bP/rds ${ }_{1-288}$ to exit from the Golgi apparatus and this region is thus essential for Golgi retention.

A Golgi accumulation of $\mathrm{bP} / \mathrm{rds}_{1-312}$ may be a consequence of inhibiting the protein's exit from the late-Golgi compartments for conventional secretion pathway and may contribute to cilia targeting through the unconventional route. To test this contribution, we studied the localization of $\mathrm{bP} / \mathrm{rds}_{\Delta 289-312}$, in which the region essential for the Golgi retention was removed but the region essential for the cilia targeting was retained. Of all of the transgene-positive cells with cilia, only $36 \%$ were strongly positive to $\mathrm{bP} / \mathrm{rds}_{\triangle 289-312}$, whereas $75 \%$ of cilia were strongly positive to $\mathrm{bP} / \mathrm{rds}$ (Fig. $5 A, C$, bP/rds-HA-FLAG and $\mathrm{bP} / \mathrm{rds}_{\triangle 289-312}$-HAFLAG). Concomitant with reduced cilia targeting, increased Endo $\mathrm{H}$ resistance of $\mathrm{bP} / \mathrm{rds}_{\triangle 289-312}$ was observed (Fig. $6 E$, bP/ $\mathrm{rds}_{\Delta 289-312}$-HA-FLAG), which is indicative of the access of $\mathrm{P} / \mathrm{rds}$ to the later Golgi compartments. Therefore, the region from 289 to 312 aa supports the cilia targeting of $\mathrm{P} / \mathrm{rds}$ through unconventional secretion, likely by inhibiting normal secretion through the conventional pathway. However, this region is not essential for cilia targeting, because $\mathrm{bP} / \mathrm{rds}_{\Delta 289-312}$ can still localize to the cilia at low efficiency.

\section{C-terminal-deficient $\mathrm{P} / \mathrm{rds}$ is incapable of reaching the} cell surface

$\mathrm{bP} / \mathrm{rds}_{1-288}$ lacks the entire CT region, which is essential for both unconventional cilia targeting and Golgi retention. We investigated whether $\mathrm{bP} / \mathrm{rds}_{1-288}$ can take the conventional secretory pathway to reach the cell surface using EZ-Link Sulfo-NHSBiotin cell surface labeling (Fig. 7A). We found that the cell surface expression of $\mathrm{bP} / \mathrm{rds}_{1-288}$ was much less pronounced than that of full-length $\mathrm{bP} / \mathrm{rds}$ in hTERT-RPE1 cells (Fig. 7A, compare $\mathrm{PM}$ in $\mathrm{bP} / \mathrm{rds}-\mathrm{HA}-\mathrm{FLAG}$ with that in $\mathrm{bP} / \mathrm{rds}_{1-288}$-HA-FLAG). We 

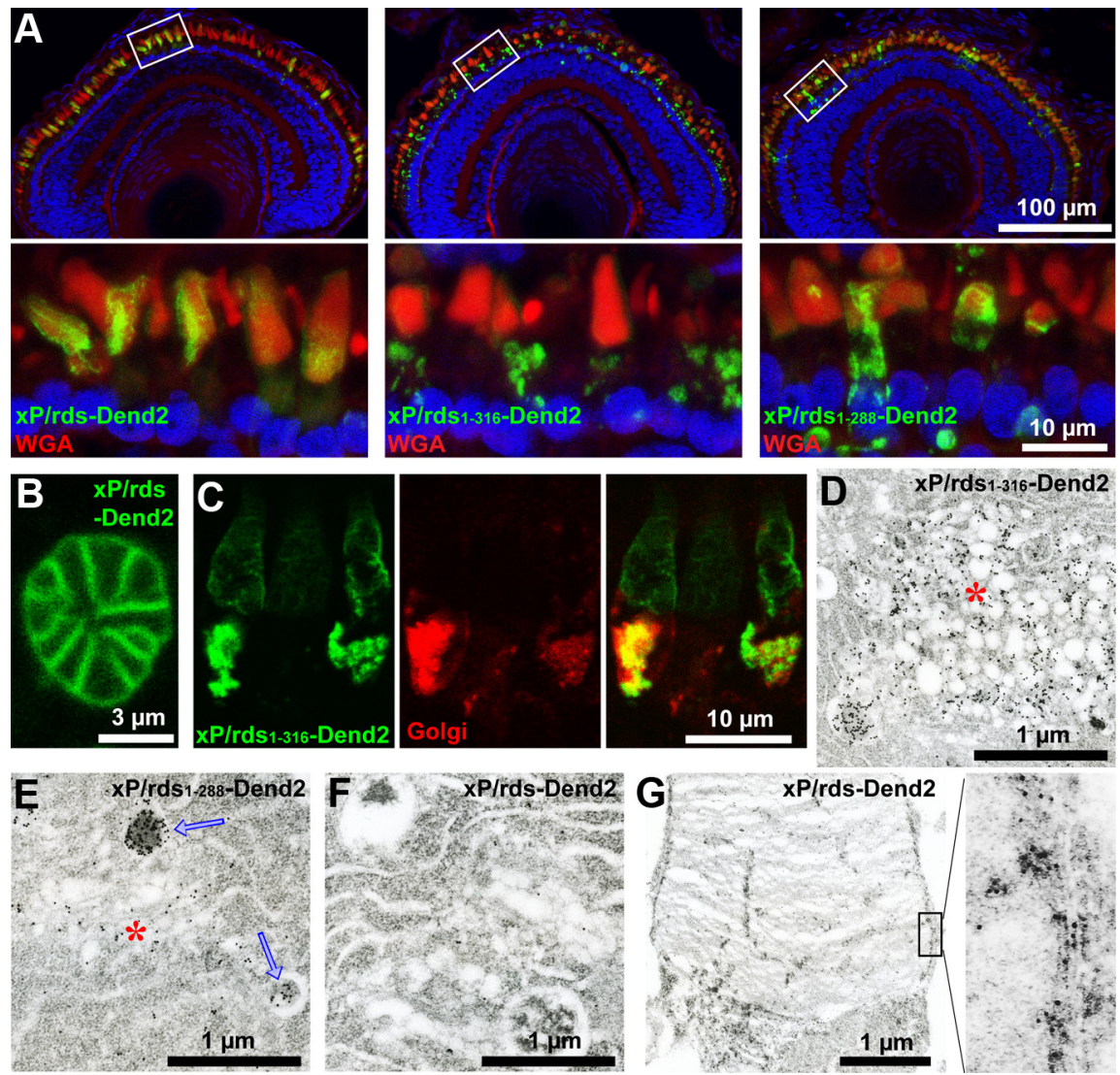

Figure 8. Mislocalization of CT-truncated xP/rds in rods. A, Localization of full-length or CT-truncated P/rds ( green) in X. laevis rods. OS areas are labeled by wheat germ agglutinin (WGA, red). Nuclei are in blue. The bottom row of images are magnified views of the selected areas above. $\boldsymbol{B}, \mathrm{xP} / \mathrm{rds}$-Dend2 (green) is localized to disk rims and incisures. $\boldsymbol{C}, \mathrm{xP} / \mathrm{rds}_{1-316}$-Dend2 (green) colocalizes with the turquoise Golgi marker (red). $\boldsymbol{D}$ - $\boldsymbol{G}$, Immunoelectron microscopy localization of CT-truncated and full-length $\mathrm{P} / \mathrm{rds}$. $\boldsymbol{D}$, xP/rds ${ }_{1-316}$-Dend2 mislocalizes in Golgi apparatus. $\boldsymbol{E}, \mathrm{xP}_{\mathrm{rds}}{ }_{1-288}$-Dend2 mislocalizes in electron-dense vesicles of the IS. $\boldsymbol{F}, \mathrm{xP} / \mathrm{rds}$ Dend2 does not localize in IS. G, xP/rds-Dend2 localizes in rim and incisures of OS. Asterisks indicate Golgi apparatus and arrows indicate electron dense vesicles. Animals were $14-15 \mathrm{~d}$ old.

also stably expressed $\mathrm{bP} / \mathrm{rds}_{1-288}$ in IMCD3 cells and confirmed that $\mathrm{bP} / \mathrm{rds}_{1-288}$ is barely expressed at the cell surface (Fig. $7 \mathrm{~A}$, IMCD3, bP/rds $\mathrm{r}_{1-288}$-HA-FLAG). Therefore, even though bP/ $\mathrm{rds}_{1-288}$ can exit the Golgi apparatus, it cannot pass through a conventional secretory route.

In IMCD3 cells, full-length $\mathrm{bP} / \mathrm{rd}$ s localized to $46.17 \pm 1.99 \%$ (mean $\pm \mathrm{SD}$ ) of the primary cilia. The majority of $\mathrm{bP} / \mathrm{rds}$ were sensitive to Endo H (Fig. 7B, bP/rds-HA-FLAG, En), suggesting that it can pass through the unconventional pathway to reach the cilia. As observed for hTERT-RPE1 cells, Golgi retention supports cilia targeting in IMCD3 cells (Fig. 7C). In the absence of the region for Golgi retention, but in the presence of the region for cilia targeting, the cilia targeting was $50 \%$ less efficient than in the presence of both regions $(22.07 \pm 1.75 \%$ of primary cilia were positive with $\mathrm{bP} / \mathrm{rds}_{\Delta 289-312}, 268$ cilia from $n=3$ preparations, compared with $46.17 \pm 1.99 \%$ with $\mathrm{bP} / \mathrm{rds}, 154$ cilia from $n=$ 3 preparations, mean $\pm \mathrm{SD}, p<0.001$ by $t$ test). Therefore, when it is present, the Golgi retention supports the cilia targeting of $\mathrm{P} / \mathrm{rds}$ and augments the unconventional secretory pathway. Unconventional cilia targeting thus operates both in IMCD3 and hTERT-RPE1 cells.

Although unconventional trafficking of full-length $\mathrm{P} / \mathrm{rds}$ was observed in both hTERT-RPE1 and IMCD3 cells, cell-linedependent variability was observed for Endo $\mathrm{H}$ resistance of CTtruncated $\mathrm{P} / \mathrm{rds}$. In the hTERT-RPE1cell line, $\mathrm{P} / \mathrm{rds}_{1-312}$, which

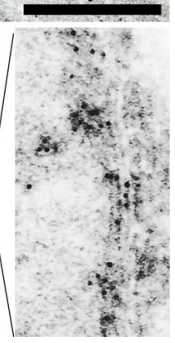

lacks the region essential for cilia targeting, was almost completely resistant to Endo H. However, in the IMCD3 cell line, $\mathrm{bP} / \mathrm{rds}_{1-312}$ was only modestly resistant to Endo $\mathrm{H}$, at a level $\sim 15 \%$ higher than that of $\mathrm{bP} / \mathrm{rds}$. This modest Endo $\mathrm{H}$ resistance in IMCD3 cells is consistent with the tendency of $\mathrm{P} / \mathrm{rds}$ to localize to earlier Golgi compartments (Fig. 7D, IMCD3). In hTERT-RPE1 cells, bP/rds ${ }_{1-312}$ was more prone to localize to late Golgi compartments (Fig. 7D, hTERT-RPE1), where it can acquire Endo $\mathrm{H}$ resistance. Likewise, $\mathrm{P} / \mathrm{rds}_{1-288}$, which lacks the entire CT tail, was highly resistant to Endo H in hTERTRPE1 cells, whereas it was modestly resistant in IMCD3 cells. Despite acquiring Endo $\mathrm{H}$ resistance and exiting the Golgi apparatus, $\mathrm{P} / \mathrm{rds}_{1-288}$ did not reach the cell surface effectively in hTERT-RPE1 cells (Fig. 7A, hTERT-RPE1). Similarly, $\mathrm{P} / \mathrm{rds}_{1}$. ${ }_{288}$ did not reach the cell surface in IMCD3 cells (Fig. 7A, IMCD3). Therefore, despite the cell-line-dependent variability, neither conventional nor unconventional secretion operates for CT-truncated $\mathrm{P} / \mathrm{rds}$ in hTERT-RPE1 and IMCD3 cells.

\section{Role of the CT tail region in the unconventional trafficking of X. laevis $\mathrm{P} / \mathbf{r d s}$}

As tested in the ciliated mammalian cells, unconventional trafficking of $\mathrm{P} / \mathrm{rds}$ is regulated by the CT regions responsible for cilia targeting and the Golgi retention. However, the information related to the Golgi localization of $\mathrm{P} / \mathrm{rds}$ has not been defined in vivo. Therefore, we used $X$. laevis rod photoreceptors to test the functional interactions between the regions regulating the cilia targeting and Golgi retention. Previously, the roles of the CT region in cilia targeting were assessed using fusions of GFP, the palmitoylation site of rhodopsin, and variously truncated CT tails of $\mathrm{P} / \mathrm{rds}$ in $X$. laevis rods (Tam et al., 2004). Although the previous study was informative in understanding cilia-targeting information, the fusion protein was a nonintegral membrane protein and may not model the unconventional trafficking of the four-transmembrane-protein $\mathrm{P} / \mathrm{rds}$. In addition, the GFP fused with the CT tails of P/rds is not glycosylated, so it is not feasible to assess the glycosylation pattern, one of the markers for unconventional trafficking. We studied the role of the CT tail region in context with the rest of the primary structure in X. laevis rod photoreceptor cells (Fig. 8). Full-length $\mathrm{xP} / \mathrm{rds}$ fused to the fluorescent protein Dend2 ( $\mathrm{xP} / \mathrm{rds}$-Dend2) localized to the disk membranes (Fig. $8 A, \mathrm{xP} / \mathrm{rds}$-Dend2) within the regions consistent with disk rims and incisures (Fig. $8 B$ ). We

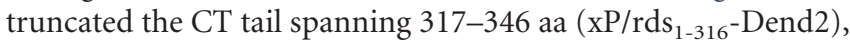
which was essential for cilia targeting in cultured cells. This $\mathrm{xP} /$ $\mathrm{rds}_{1-316}$-Dend2 localized predominantly in the intracellular structures in the photoreceptor IS (Fig. $8 A, \mathrm{xP} / \mathrm{rds}_{1-316}$-Dend2). These structures partially colocalized with a turquoise transGolgi marker (Fig. 8C), indicative of Golgi localization of $\mathrm{xP} /$ $\mathrm{rds}_{1-316}$-Dend2. To further understand the region required for Golgi retention, the additional region (289-316 aa) was removed 
from $\mathrm{xP} / \mathrm{rds}_{1-316}$ to create $\mathrm{xP} / \mathrm{rds}_{1-288}$. Similar to $\mathrm{xP} / \mathrm{rds}_{1-316^{-}}$Dend2, $\mathrm{xP} / \mathrm{rds}_{1-288^{-}}$ Dend 2 localized to IS punctate structures, as observed by fluorescence microscopy

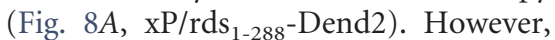
unlike $\mathrm{xP} / \mathrm{rds}_{1-316}$-Dend2, which localized to the Golgi apparatus (Fig. $8 D$, asterisk), $\mathrm{xP} / \mathrm{rds}_{1-288}$-Dend2 was not enriched in the Golgi apparatus (Fig. 8E, asterisk), as revealed by immunoelectron microscopy. $\mathrm{xP} / \mathrm{rds}_{1-288}$-Dend2 was concentrated in electron-dense vesicle structures (Fig. 8E, arrows). $\mathrm{xP} / \mathrm{rds}$-Dend 2 did not accumulate in the Golgi or vesicular structures (Fig. $8 F$ ) and, as expected, was observed in the rim region of the disk membranes (Fig. 8G). The CT region required for Golgi retention is thus operational in $X$. laevis rods.

CT-truncated $\mathrm{xP} / \mathrm{rds}_{1-316}$ and $\mathrm{xP} / \mathrm{rds}_{1-}$ 288 were also observed in the OS (Figs. 9, 10, $\mathrm{xP} / \mathrm{rds}_{1-316^{-}}$Dend2 and $\mathrm{xP} / \mathrm{rds}_{1-288^{-}}$ Dend2). By oligomerizing with endogenous $\mathrm{P} / \mathrm{rds}$ with an intact trafficking signal, CT-deficient $\mathrm{P} / \mathrm{rds}$ can be brought to the OS (Ritter et al., 2011; Salinas et al., 2013). However, the qualitative localization studies cannot evaluate whether CT-

tail-deficient $\mathrm{P} / \mathrm{rds}$ are trafficked to the OS as efficiently as the full-length $\mathrm{P} / \mathrm{rds}$. To understand quantitatively the efficiency of OS targeting for $\mathrm{xP} / \mathrm{rds}_{1-316}$ and $\mathrm{xP} / \mathrm{rds}_{1-288}$ compared with $\mathrm{xP} /$ rds, we used a fluorescent protein-based quantification method (Fig. 9). Antibody-based fluorescence methods are not suitable for quantification due to poor penetration of antibody into the densely packed disk membranes of chemically fixed rods (Tam et al., 2006). Such poor penetration poses a difficulty in accurately calibrating the antibody signals to known molar quantities of standard proteins in nontissue environments. In this experiment, the fluorescence intensities were calibrated to known quantities of soluble Dend 2 to obtain molar concentrations in the OS and IS of individual rods (Fig. 9A). OS targeting of $\mathrm{xP} / \mathrm{rds}$-Dend 2 was efficient, as demonstrated by the majority of cells with OS concentrations $>3 \mu \mathrm{M}$ and the small fraction (23\%) lower than $3 \mu \mathrm{M}$ (Fig. $9 B, \mathrm{xP} / \mathrm{rds}$-Dend2). No appreciable mislocalization of $\mathrm{xP} / \mathrm{rds}-$ Dend2 was observed in the IS (Fig. $9 A, B, \mathrm{xP} / \mathrm{rds}$-Dend2). We found that OS trafficking of $\mathrm{xP} / \mathrm{rds}_{1-316}$-Dend 2 was compromised, as demonstrated by the majority ( $94.9 \%$ ) of cells with concentrations lower than $3 \mu \mathrm{M}$ (Fig. $9 B, \mathrm{xP} / \mathrm{rds}_{1-316}$-Dend2). The release from the Golgi apparatus resulted in the OS trafficking of $\mathrm{xP} / \mathrm{rds}_{1-288^{-}}$ Dend2 being as efficient as that of $\mathrm{xP} / \mathrm{rds}$-Dend2 (22\% lower than $3 \mu \mathrm{M}$; Fig. $9 B, \mathrm{xP} / \mathrm{rds}_{1-288}$-Dend2).

The low OS concentrations of $\mathrm{xP} / \mathrm{rds}_{1-316}$-Dend 2 are therefore due to protein retention in the Golgi apparatus. Accordingly, the IS to OS concentration ratio, derived from the data points in the scatter plot (Fig. $9 B$ ), was significantly higher for $\mathrm{xP} / \mathrm{rds}_{1-316}$ than for $\mathrm{xP} / \mathrm{rds}_{1-288}$ $(p=0.039$ by MWRST $)$ and $\mathrm{xP} / \mathrm{rds}(p<0.001$ by MWRST; Fig. $9 C)$. In this analysis, high variability of expression levels was observed among individual cells, as described previously for this transient X. laevis transient transgenic system (Moritz et al., 2001). This variable cellular expression was advantageous when combined with single cell analysis, because this combination allowed us to inquire whether the IS mislocalizations of $\mathrm{xP} / \mathrm{rds}_{1-316}$ and $\mathrm{xP} / \mathrm{rds}_{1-288}$ are due to overexpression. We found that $\mathrm{xP} / \mathrm{rds}_{1-316}$-Dend 2 and $\mathrm{xP} / \mathrm{rds}_{1-}$
${ }_{288}$-Dend 2 were mislocalized in the IS without correlation with the different OS concentration and expression levels (Fig. 9B). Within the OS, the molar ratio of $\mathrm{P} / \mathrm{rds}$ to rhodopsin is estimated to be $\sim$ 1:90 (Goldberg and Molday, 1996). Given that the rhodopsin concentration is $\sim 3 \mathrm{~mm}$ (Haeri and Knox, 2012), the $\mathrm{P} / \mathrm{rds}$ concentration would be $\sim 30 \mu \mathrm{M}$. The OS concentrations of $\mathrm{xP} / \mathrm{rds}$-Dend2, $\mathrm{xP} / \mathrm{rds}_{1-316}$-Dend2, and $\mathrm{xP} / \mathrm{rds}_{1-288}$-Dend 2 did not exceed 10 $\mu \mathrm{M}$ (Fig. $9 B$ ), indicating that the expression levels of $\mathrm{xP} / \mathrm{rds}$-Dend 2 constructs were lower than that of endogenous $\mathrm{P} / \mathrm{rds}$. The observed IS localizations of $\mathrm{xP} / \mathrm{rds}_{1-316}$-Dend 2 and $\mathrm{xP} / \mathrm{rds}_{1-288}$-Dend 2 are thus not due to $\mathrm{P} / \mathrm{rds}$ overexpression.

To understand the dynamics of $\mathrm{P} / \mathrm{rds}$ trafficking, we applied a photoconversion technique that takes advantage of the photoconvertible fluorescent protein Dend2 (Gurskaya et al., 2006; Chudakov et al., 2007), which allowed us to discriminate newly synthesized proteins in green from old proteins in red (Lodowski et al., 2013; Fig. 10). We focused on the renewal of P/rds in the OS to understand whether OS targeting is compromised for CTtruncated P/rds. Right after photoconversion, the photoreceptor was occupied with red Dend2 fusion proteins (Fig. 10A). Four hours (Fig. 10B) and $48 \mathrm{~h}$ (Fig. 10C) after photoconversion, newly synthesized green $\mathrm{xP} / \mathrm{rds}$-Dend 2 was observed in the basal part of the OS, whereas old $\mathrm{xP} / \mathrm{rds}$-Dend2 localized to a more distal portion of the OS (Fig. $10 B, C, \mathrm{xP} / \mathrm{rds}$-Dend2). These observations are consistent with the displacement of old $\mathrm{xP} / \mathrm{rds}$, with new $\mathrm{xP} / \mathrm{rds}$ being synchronized with the process of disk morphogenesis and maintenance. Similar OS renewal was observed for $\mathrm{xP} / \mathrm{rds}_{1-316}$ and $\mathrm{xP} / \mathrm{rds}_{1-288}$. However, $\mathrm{xP} / \mathrm{rds}_{1-316}$ demonstrated dimmer Dend 2 fluorescence (Fig. 10A-C), which is consistent with the generally low OS concentrations of $\mathrm{xP} / \mathrm{rds}_{1-316}$ (Fig. 9B,C). Therefore, the low OS concentration of $\mathrm{xP} / \mathrm{rds}_{1-316}$ is not due to slowed disk membrane morphogenesis.

We then focused on the dynamics of protein trafficking and renewal in the IS. A high concentration of $\mathrm{xP} / \mathrm{rds}_{1-316}$-Dend 2 in the Golgi apparatus (Fig. 8C) leads to the question of whether the exit of proteins from the Golgi apparatus is slowed or if proteins 

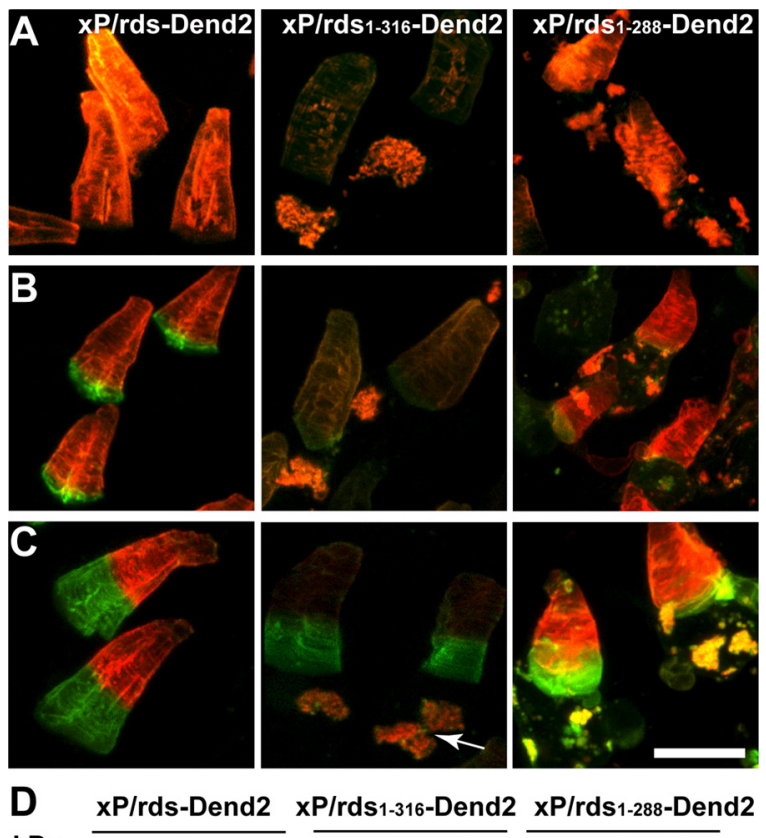

xP/rds1-316-Dend2 xP/rds1-288-Dend2

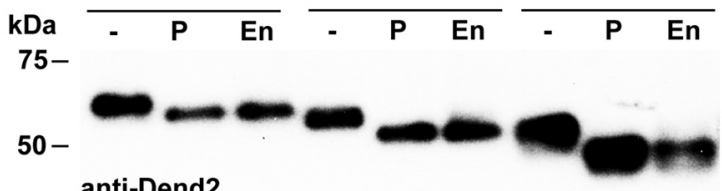

anti-Dend2

Figure 10. CT-truncated $\mathrm{P} / \mathrm{rd}$ s retained in $\mathrm{IS}$ are slow in renewal. $\boldsymbol{A}-\boldsymbol{C}$, Dend 2 fluorescence of live retinal explants (maximum projections) $0 \mathrm{~h}(\boldsymbol{A}), 4 \mathrm{~h}(\boldsymbol{B})$, or $48 \mathrm{~h}(\boldsymbol{C})$ after photoconversion. $x P / r_{1-316}$ in the IS does not exit the Golgiapparatus for $>48$ h. D, PNGase F $(P)$ and Endo $H$ (En) analysis of tadpole eyes expressing full-length and CT-truncated $\mathrm{P} / \mathrm{rds}$. CT-truncated $\mathrm{P} / \mathrm{rds}$ are sensitive to Endo $\mathrm{H}$ similar to full-length $\mathrm{P} / \mathrm{rds}$. Animals were $10 \mathrm{~d}$ old in $\boldsymbol{A}-\boldsymbol{C}$ and $14-15 \mathrm{~d}$ old in $D$.

are retained and unable to exit the Golgi apparatus. To determine which of these two mechanisms is correct, we studied how $\mathrm{xP} / \mathrm{rds}_{1-316}$-Dend 2 is renewed in the IS. Four hours after photoconversion, the IS structure was almost exclusively composed of old $\mathrm{xP} / \mathrm{rds}_{1-316}$-Dend2 (Fig. $10 \mathrm{~B}, \mathrm{xP} / \mathrm{rds}_{1-316}$-Dend2), suggesting that $\mathrm{xP} / \mathrm{rds}_{1-316}$-Dend2 was retained in and unable to exit the Golgi apparatus. Forty-eight hours after photoconversion, old protein (red) still occupied the majority of the IS structures (Fig. 10C, $\mathrm{xP} / \mathrm{rds}_{1-316}$-Dend2). New proteins were added to the periphery of the IS structures (Fig. $10 C, \mathrm{xP} / \mathrm{rds}_{1-316}$-Dend2, arrow), which is suggestive of gradual inflation of the Golgi apparatus and the lack of protein renewal. Consistent with the inflation of the structure, an enlargement of the Golgi apparatus was observed in rods expressing $\mathrm{xP} / \mathrm{rds}_{1-316}$-Dend2 by immunoelectron microscopy (Fig. $8 D$ ). These observations suggest that $\mathrm{xP} / \mathrm{rds}_{1-316}$ causes the abnormal maintenance of the Golgi apparatus due to its aberrant Golgi accumulation. Unlike $\mathrm{xP} / \mathrm{rds}_{1-316}, \mathrm{xP} / \mathrm{rds}_{1-288}$ did not cause inflation of the Golgi apparatus. Within the IS structures, a subpopulation of $\mathrm{xP} / \mathrm{rds}_{1-288}$ appeared to be renewed slowly from 4 to $48 \mathrm{~h}$ (Fig. $10 \mathrm{~B}, \mathrm{C}, \mathrm{xP} / \mathrm{rds}_{1-288}$-Dend2), as indicated by the coexistence of new and old proteins at $48 \mathrm{~h}$ after photoconversion (Fig. 10C, $\mathrm{xP} / \mathrm{rds}_{1-288}$-Dend2, yellow). In conjunction with the high OS concentrations of $\mathrm{xP} / \mathrm{rds}_{1-288}$, these photoconversion results suggest that $\mathrm{xP} / \mathrm{rds}_{1-288}$ can leave the IS for OS targeting more readily than $\mathrm{xP} / \mathrm{rds}_{1-316}$. Therefore, Golgi retention sequesters $\mathrm{xP} / \mathrm{rds}_{1-316}$ in the IS and the loss of Golgi retention released $\mathrm{xP} / \mathrm{rds}_{1-288}$ toward the OS.
As observed in IMCD3 cells, CT-truncated P/rds-Dend2 demonstrated robust Endo $\mathrm{H}$ sensitivity similar to $\mathrm{xP} / \mathrm{rds}$-Dend 2 in $X$. laevis rods (Fig. 10D). Therefore, although full-length and CT-truncated $\mathrm{P} / \mathrm{rds}$-Dend2s were observed in the OS, it is unlikely that they passed through the conventional secretion. In summary, these studies on $X$. laevis are consistent with $\mathrm{P} / \mathrm{rds}^{\prime}$ passing through the unconventional secretion (Fig. 11). The removal of the region contributing to cilia targeting causes $\mathrm{P} / \mathrm{rds}_{1-312}$ or $\mathrm{P} / \mathrm{rds}_{1-316}$ to accumulate in the Golgi apparatus in both $X$. laevis and mammalian cultured cells (Fig. 11A). This is due to the Golgi retention information located in the CT region 289312 aa. Further removal of the region allowed $\mathrm{P} / \mathrm{rds}_{1-288}$ to exit the Golgi apparatus, but led to its mislocalization to intracellular vesicular structures (Fig. 11 A,B). Therefore, in both mammalian cells and $X$. laevis rods, the regions regulating cilia targeting and Golgi retention are required for the proper subcellular localization of $\mathrm{P} / \mathrm{rds}$.

\section{Discussion}

$\mathrm{P} / \mathrm{rds}$ passes through an unconventional trafficking pathway to be delivered to the primary cilia. This unconventional pathway is distinct from previously described GRASP55-mediated secretion (Gee et al., 2011). P/rds bypasses at least a part of the Golgi apparatus, where glycoproteins acquire a complex glycan and Endo $\mathrm{H}$ resistance, and also the TGN. Because of this bypass, P/rds targeted to the primary cilia lacks Endo $\mathrm{H}$ resistance in both photoreceptor cells in vivo and two ciliated mammalian cell lines, hTERT-RPE1 and IMCD3 (summarized in Fig. 11). Endo H sensitivity was documented previously in bovine retina (Connell and Molday, 1990) and was consistently observed when P/rds was expressed in COS-1 (Goldberg et al., 1995) and MDCK cells (Muller-Weeks et al., 2002; Stefano et al., 2002). P/rds was barely observed in the Golgi apparatus when expressed at low levels in hTERT-RPE1 cells. Similar low expression of P/rds was accomplished with AD293 cells, in which P/rds was barely observed in the Golgi apparatus (Khattree et al., 2013). Our study indicates that the observed Endo $\mathrm{H}$ sensitivity of $\mathrm{P} / \mathrm{rds}$ is not due to its inability to serve as a substrate for the GMII enzyme. In hTERTRPE1 cells, truncation of the CT tail led $\mathrm{bP} / \mathrm{rds}_{1-312}$ to localize predominantly in the TGN, an indication that $\mathrm{bP} / \mathrm{rds}_{1-312}$ passed through the mid- and trans-Golgi compartments, where bP/ $\mathrm{rds}_{1-312}$ served as a substrate for GMII and acquired robust Endo $\mathrm{H}$ resistance. To exclude the possible involvement of conventional trafficking, we applied BFA, 30N12, and monensin, which are known to block conventional secretion. Because these treatments were highly toxic to the photoreceptor neurons and the organism, adequate assessment of $\mathrm{P} / \mathrm{rds}$ trafficking has been challenging for in vivo studies. Therefore, we took advantage of ciliated hTERT-RPE1 cells in which P/rds was precisely targeted to the primary cilia and blockage of conventional secretion was well tolerated for a short period of time. In hTERT-RPE1 cells, a trace amount of full-length $\mathrm{bP} / \mathrm{rds}$ was Endo $\mathrm{H}$ resistant. However, Endo H-resistant P/rds was abolished by BFA and 30N12, indicating that these treatments blocked the conventional secretion effectively. As assessed by FRAP, the $30 \mathrm{~N} 12$ and monensin treatments, which inhibited the conventional trafficking of SSTR3, allowed the trafficking of $\mathrm{bP} / \mathrm{rds}$ to the primary cilia. Therefore, the conventional secretory pathway is not essential for cilia targeting of $\mathrm{P} / \mathrm{rds}$.

$\mathrm{P} / \mathrm{rds}$ and rhodopsin are trafficked in different ways: via unconventional and conventional secretion, respectively. Through conventional secretion, rhodopsin carrier cargoes bud from the trans-Golgi apparatus to be directed to the cilia (Deretic and 
Papermaster, 1991; Deretic et al., 2005; Mazelova et al., 2009; Wang et al., 2012). In detached cat retinas, rhodopsin localized to the somatic plasma membrane, whereas $\mathrm{P} / \mathrm{rds}$ localized to intracellular membrane compartments (Fariss et al., 1997). Intracellular localization of $\mathrm{P} / \mathrm{rds}$ is consistent with our observation that $\mathrm{P} / \mathrm{rds}$ cannot take the conventional secretory route as a default pathway and accordingly accumulates in the intracellular compartments in the absence of active cilia targeting. Genetic evidence also suggests that $\mathrm{P} / \mathrm{rds}$ and rhodopsin use different machineries at the late stage of trafficking to pass through the connecting cilia toward the OS. (Zhao and Malicki, 2011). The OS is mainly divided into two subcompartments: the disk membrane and plasma membrane. Rhodopsin is targeted to the disk membrane and plasma membrane of the OS (Basinger et al., 1976). $\mathrm{P} / \mathrm{rds}$ is targeted to the disk membranes specifically (Fig. $8 A, B$ ). Such specific targeting of $\mathrm{P} / \mathrm{rds}$ would be accomplished by an unconventional pathway that does not deliver protein to the somatic plasma membrane effectively.

The unconventional cilia targeting of $\mathrm{P} / \mathrm{rds}$ is supported by at least two distinct regions that are essential for the cilia targeting and the Golgi retention, respectively. Both regions operate in photoreceptors, hTERT-RPE1, and IMCD3 cells. For the OS targeting of $\mathrm{P} / \mathrm{rds}$, the $\mathrm{CT}$ tail region from 317 to 336 aa plays an important role, as demonstrated by Tam et al. (2004). More recently, Salinas et al. (2013) demonstrated that the CT region from 327 to 336 aa is sufficient for this OS targeting, especially the valine at position 332. By removing the CT region from 331 to 336 aa, which also contains this critical valine residue, $\mathrm{P} / \mathrm{rds}$ was no longer targeted to the primary cilia of hTERT-RPE1 cells. These results suggest that photoreceptors and hTERT-RPE1 cells share the same specific cilia-targeting mechanism, so hTERT-RPE1 is an appropriate model for the study of photoreceptor sensory cilia targeting. In addition to the specific mechanism, however, the photoreceptor may facilitate the cilia trafficking of proteins, also by a default mechanism (Baker et al., 2008), making the detailed assessment of trafficking information difficult. By taking advantage of hTERTRPE1 cells, we found that a neighboring sequence from 337 to 342 aa plays a supportive role in enriching $\mathrm{P} / \mathrm{rd}$ s to the primary cilia. In the absence of this collective cilia-targeting/enrichment information, $\mathrm{P} / \mathrm{rds}_{1-330}$ distributed to intracellular membrane compartments, with poor localization to the plasma membrane. It is unlikely that this poor plasma membrane localization is due to compromised fusogenic activity of $\mathrm{P} / \mathrm{rds}$ conferred by the CT tail of $\mathrm{P} / \mathrm{rds}$. Poor

\begin{tabular}{|c|c|c|c|c|c|c|}
\hline 1 & \multicolumn{3}{|c|}{ Xenopus laevis } & \multicolumn{3}{|c|}{ Mammalian cells } \\
\hline & \multirow{2}{*}{ OS } & \multicolumn{2}{|c|}{ IS } & \multirow{2}{*}{ Cilia } & \multicolumn{2}{|c|}{$\begin{array}{c}\text { Intracellular } \\
\text { structures }\end{array}$} \\
\hline & & Golgi & vesicles & & Golgi & vesicles \\
\hline P/rds & ++ & $+1-$ & $+1-$ & ++ & $+1-$ & $+1-$ \\
\hline $\begin{array}{l}\text { P/rds }_{1-316} \text { or } \\
\text { P/rds }_{1-312}\end{array}$ & + & ++ & $+1-$ & - & ++ & $+1-$ \\
\hline $\mathrm{P} / \mathrm{rds}_{1-288}$ & ++ & + & + & - & + & + \\
\hline
\end{tabular}

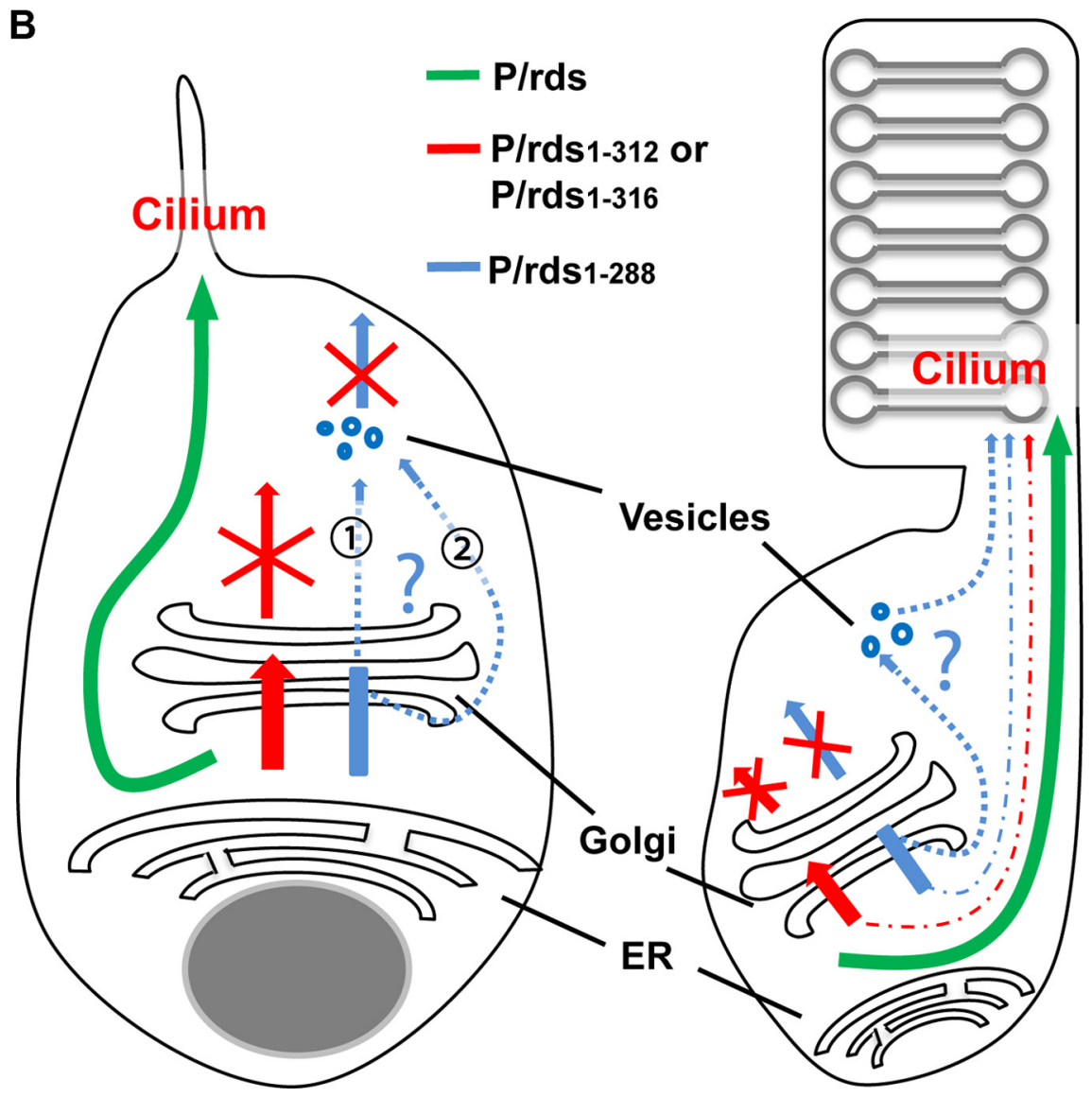

Figure 11. Model for unconventional cilia targeting of $\mathrm{P} / \mathrm{rds}$. $A$, The summarized localizations of $\mathrm{P} / \mathrm{rds}$ and the $\mathrm{CT}$ truncations in photoreceptor cells and mammalian cells.,,$++++/-$, and - indicate that the transgenes' signals were strong, weak, very weak, and undetectable, respectively. Note: When overexpressed in mammalian cells, P/rds can also be detected in Golgi and other intracellular compartments. $\boldsymbol{B}$, In both mammalian cells (left) and $X$. laevis rods (right), $P /$ rds bypasses the Golgi apparatus, either the later portions or altogether, to reach the cilia, thus taking an unconventional secretory pathway (green arrow, $\mathrm{P} / \mathrm{rds}$ ). The Golgi retention signal prevents conventional secretion of $\mathrm{P} / \mathrm{rds}_{1-312}$ or $\mathrm{P} / \mathrm{rds}_{1-316}$ (red arrow, $\mathrm{P} / \mathrm{rds}_{1-312}$ or $\mathrm{P} / \mathrm{rds}_{1-316}$ ), but does not block unconventional cilia targeting in rods (red dash-dotted arrow), likely due to trafficking driven by oligomerization with endogenous $\mathrm{P} / \mathrm{rds}$. After release from Golgi (left, blue dotted arrow, $\left.\mathrm{P} / \mathrm{rds}_{1-288}\right), \mathrm{P} / \mathrm{rds}_{1-288}$ is incapable of taking the secretory pathway in mammalian cells (left, blue arrow). Routes labeled 1 and 2 are the estimated routes explaining the cell-line-dependent variability observed between hTERT-RPE1 and IMCD3 cells. Neither 1 or 2 is a complete secretory pathway and cannot deliver P/rds ${ }_{1-288}$ to the cell surface. P/rds ${ }_{1-288}$ can reach the cilium through unconventional secretion in rods (right, blue dotted and dash-dotted arrows). plasma membrane localization was observed for $\mathrm{bP} / \mathrm{rds}_{1-330}$, for which the fusogenic region 312-326 aa (Damek-Poprawa et al., 2005) is intact. A tendency to localize inside the cell, observed for $\mathrm{bP} / \mathrm{rds}_{1-312}$, is also not consistent with the loss of fusogenic activity, because retention in the Golgi apparatus suggests compromised exit and membrane fission, not fusion activity. Because of the tendency to localize inside the cell, 
$\mathrm{P} / \mathrm{rds}$ cannot be delivered to the plasma membrane by a default conventional secretory route in the absence of unconventional cilia targeting (Fig. 11B, left, blue arrows).

$\mathrm{P} / \mathrm{rds}$ appears to be prevented from exiting the TGN (Fig. 11B, red arrows, $\mathrm{P} / \mathrm{rds}_{1-312}$ or $\left.\mathrm{P} / \mathrm{rds}_{1-316}\right)$. This prevention is important for cilia targeting because removal of the preventive region (289312 aa) from $\mathrm{P} / \mathrm{rds}$ led to compromised cilia targeting, with a concomitant increase in the Endo $\mathrm{H}$ resistance of $\mathrm{P} / \mathrm{rds}_{\Delta 289-312}$. This prevention was also observed in X. laevis rod photoreceptors (Fig. $11 B$, red arrows, $\mathrm{P} / \mathrm{rds}_{1-312}$ or $\mathrm{P} / \mathrm{rds}_{1-316}$ ). Using the photoconversion technique, we found that this Golgi retention mechanism can prevent $\mathrm{P} / \mathrm{rds}$ from entering the secretory pathway and, accordingly, $\mathrm{P} / \mathrm{rds}_{1-316}$ stayed in the Golgi compartment for $48 \mathrm{~h}$. Release from this Golgi retention allowed $\mathrm{P} / \mathrm{rds}_{1-288}$ for secretion, likely through an oligomerization-driven unconventional secretory pathway in rod photoreceptor cells (Fig. 11B, right, blue arrows); however, a subpopulation of $\mathrm{P} / \mathrm{rds}_{1-288}$ was stuck in the IS electron-dense vesicles. One of the major advantages of using ciliated cells is the apparent absence of oligomerization-driven cilia targeting. Therefore, both $\mathrm{P} / \mathrm{rds}_{1-312}$ and $\mathrm{P} / \mathrm{rds}_{1-288}$ were incapable of passing through the secretory pathway in hTERT-RPE1 and IMCD3 cells and were not targeted to the cilia (Fig. 11B, left, red and blue arrows).

Golgi retention appears to be nonessential but supportive for unconventional secretion and cilia targeting of $\mathrm{P} / \mathrm{rds}$. Accordingly, BFA-treated cells in which the function of the entire Golgi was compromised still maintained P/rds in the cilia with a slight compromise in cilia trafficking, as assessed by FRAP. The nonessential but supportive role of Golgi retention was also indicated from the study of $\mathrm{bP} / \mathrm{rds}_{\Delta 289-312}$, which lacks the region essential for Golgi retention. $\mathrm{bP} / \mathrm{rds}_{\triangle 289-312}$ was trafficked to the cilia, indicating that the region from 289 to 312 aa is not essential for cilia targeting. However, some compromise in the cilia targeting was observed, suggesting the supportive role of this region. Golgi retention is a likely mechanism to locate $\mathrm{P} / \mathrm{rds}$ proximal to the exit sites for unconventional secretion. For example, $\mathrm{P} / \mathrm{rds}$ retained in the Golgi apparatus would be retrieved to the ER, where P/rds exits for unconventional secretion. The essential role of the ER is indicated from COPII dependency for the cilia targeting of $\mathrm{P} / \mathrm{rds}$. Alternatively, $\mathrm{P} / \mathrm{rds}$ temporarily retained in the Golgi apparatus may exit from the cis-Golgi, as observed for polycystin 2 (Hoffmeister et al., 2011). Our observations are consistent with a partial involvement of early Golgi compartments in the cilia targeting of $\mathrm{P} / \mathrm{rds}$.

In summary, here, we provide evidence that $\mathrm{P} / \mathrm{rds}$ is trafficked through an unconventional pathway. How the unconventional pathway cooperates with the conventional pathway is a question pertinent to the morphogenesis and function of the OS. The unconventional pathway may sequester $\mathrm{P} / \mathrm{rds}$ from the trafficking routes of other photoreceptor proteins such as GARPs (Poetsch et al., 2001), ROM1(Bascom et al., 1992), and melanoregulin (Boesze-Battaglia et al., 2007), which interact with $\mathrm{P} / \mathrm{rds}$. The $\mathrm{P} / \mathrm{rds}$-GARP or $\mathrm{P} / \mathrm{rds}$-channel interaction is suggested to play important roles in disk morphogenesis and maintenance (Poetsch et al., 2001; Zhang et al., 2009). The P/rds-GARP interaction can start to occur at the place and timing of disk morphogenesis, as revealed by an in situ fluorescence complementation approach (Ritter et al., 2011). Using both conventional and unconventional routes for trafficking, photoreceptors may regulate protein-protein interactions in a spatiotemporal manner.

\section{References}

Aridor M, Bannykh SI, Rowe T, Balch WE (1995) Sequential coupling between COPII and COPI vesicle coats in endoplasmic reticulum to Golgi transport. J Cell Biol 131:875-893. CrossRef Medline

Arikawa K, Molday LL, Molday RS, Williams DS (1992) Localization of peripherin/rds in the disk membranes of cone and rod photoreceptors: relationship to disk membrane morphogenesis and retinal degeneration. J Cell Biol 116:659-667. CrossRef Medline

Baker SA, Haeri M, Yoo P, Gospe SM 3rd, Skiba NP, Knox BE, Arshavsky VY (2008) The outer segment serves as a default destination for the trafficking of membrane proteins in photoreceptors. J Cell Biol 183:485-498. CrossRef Medline

Bascom RA, Manara S, Collins L, Molday RS, Kalnins VI, McInnes RR (1992) Cloning of the cDNA for a novel photoreceptor membrane protein (rom-1) identifies a disk rim protein family implicated in human retinopathies. Neuron 8:1171-1184. CrossRef Medline

Basinger S, Bok D, Hall M (1976) Rhodopsin in the rod outer segment plasma membrane. J Cell Biol 69:29-42. CrossRef Medline

Berbari NF, Johnson AD, Lewis JS, Askwith CC, Mykytyn K (2008) Identification of ciliary localization sequences within the third intracellular loop of G-protein-coupled receptors. Mol Biol Cell 19:1540-1547. CrossRef Medline

Boehlke C, Bashkurov M, Buescher A, Krick T, John AK, Nitschke R, Walz G, Kuehn EW (2010) Differential role of Rab proteins in ciliary trafficking: Rab23 regulates smoothened levels. J Cell Sci 123:1460-1467. CrossRef Medline

Boesze-Battaglia K, Song H, Sokolov M, Lillo C, Pankoski-Walker L, Gretzula C, Gallagher B, Rachel RA, Jenkins NA, Copeland NG, Morris F, Jacob J, Yeagle P, Williams DS, Damek-Poprawa M (2007) The tetraspanin protein peripherin-2 forms a complex with melanoregulin, a putative membrane fusion regulator. Biochemistry 46:1256-1272. CrossRef Medline

Chudakov DM, Lukyanov S, Lukyanov KA (2007) Tracking intracellular protein movements using photoswitchable fluorescent proteins PS-CFP2 and Dendra2. Nat Protoc 2:2024-2032. CrossRef Medline

Connell GJ, Molday RS (1990) Molecular cloning, primary structure, and orientation of the vertebrate photoreceptor cell protein peripherin in the rod outer segment disk membrane. Biochemistry 29:46914698. CrossRef Medline

Damek-Poprawa M, Krouse J, Gretzula C, Boesze-Battaglia K (2005) A novel tetraspanin fusion protein, peripherin-2, requires a region upstream of the fusion domain for activity. J Biol Chem 280:9217-9224. CrossRef Medline

Deretic D, Papermaster DS (1991) Polarized sorting of rhodopsin on postGolgi membranes in frog retinal photoreceptor cells. J Cell Biol 113:12811293. CrossRef Medline

Deretic D, Williams AH, Ransom N, Morel V, Hargrave PA, Arendt A (2005) Rhodopsin $\mathrm{C}$ terminus, the site of mutations causing retinal disease, regulates trafficking by binding to ADP-ribosylation factor 4 (ARF4). Proc Natl Acad Sci U S A 102:3301-3306. CrossRef Medline

Fariss RN, Molday RS, Fisher SK, Matsumoto B (1997) Evidence from normal and degenerating photoreceptors that two outer segment integral membrane proteins have separate transport pathways. J Comp Neurol 387:148-156. CrossRef Medline

Farjo R, Skaggs JS, Nagel BA, Quiambao AB, Nash ZA, Fliesler SJ, Naash MI (2006) Retention of function without normal disc morphogenesis occurs in cone but not rod photoreceptors. J Cell Biol 173:59-68. CrossRef Medline

Gee HY, Noh SH, Tang BL, Kim KH, Lee MG (2011) Rescue of DeltaF508CFTR trafficking via a GRASP-dependent unconventional secretion pathway. Cell 146:746-760. CrossRef Medline

Giuliani F, Grieve A, Rabouille C (2011) Unconventional secretion: a stress on GRASP. Curr Opin Cell Biol 23:498-504. CrossRef Medline

Goedhart J, von Stetten D, Noirclerc-Savoye M, Lelimousin M, Joosen L, Hink MA, van Weeren L, Gadella TW Jr, Royant A (2012) Structureguided evolution of cyan fluorescent proteins towards a quantum yield of 93\%. Nat Commun 3:751. CrossRef Medline

Goldberg AF, Molday RS (1996) Subunit composition of the peripherin/ rds-rom-1 disk rim complex from rod photoreceptors: hydrodynamic evidence for a tetrameric quaternary structure. Biochemistry 35:61446149. CrossRef Medline

Goldberg AF, Moritz OL, Molday RS (1995) Heterologous expression of photoreceptor peripherin/rds and Rom-1 in COS-1 cells: assembly, inter- 
actions, and localization of multisubunit complexes. Biochemistry 34 : 14213-14219. CrossRef Medline

Grieve AG, Rabouille C (2011) Golgi bypass: skirting around the heart of classical secretion. Cold Spring Harb Perspect Biol 3:1-15. CrossRef Medline

Gurskaya NG, Verkhusha VV, Shcheglov AS, Staroverov DB, Chepurnykh TV, Fradkov AF, Lukyanov S, Lukyanov KA (2006) Engineering of a monomeric green-to-red photoactivatable fluorescent protein induced by blue light. Nat Biotechnol 24:461-465. CrossRef Medline

Haeri M, Knox BE (2012) Rhodopsin mutant P23H destabilizes rod photoreceptor disk membranes. PLoS One 7:e30101. CrossRef Medline

Hoffmeister H, Babinger K, Gürster S, Cedzich A, Meese C, Schadendorf K, Osten L, de Vries U, Rascle A, Witzgall R (2011) Polycystin-2 takes different routes to the somatic and ciliary plasma membrane. J Cell Biol 192:631-645. CrossRef Medline

Khattree N, Ritter LM, Goldberg AF (2013) Membrane curvature generation by a C-terminal amphipathic helix in peripherin-2/rds, a tetraspanin required for photoreceptor sensory cilium morphogenesis. J Cell Sci 126: 4659-4670. CrossRef Medline

Kim J, Lee JE, Heynen-Genel S, Suyama E, Ono K, Lee K, Ideker T, Aza-Blanc P, Gleeson JG (2010) Functional genomic screen for modulators of ciliogenesis and cilium length. Nature 464:1048-1051. CrossRef Medline

Kuehn MJ, Herrmann JM, Schekman R (1998) COPII-cargo interactions direct protein sorting into ER-derived transport vesicles. Nature 391:187190. CrossRef Medline

Lodowski KH, Lee R, Ropelewski P, Nemet I, Tian G, Imanishi Y (2013) Signals governing the trafficking and mistrafficking of a ciliary GPCR, rhodopsin. J Neurosci 33:13621-13638. CrossRef Medline

Loewen CJ, Moritz OL, Tam BM, Papermaster DS, Molday RS (2003) The role of subunit assembly in peripherin-2 targeting to rod photoreceptor disk membranes and retinitis pigmentosa. Mol Biol Cell 14:3400-3413. CrossRef Medline

MacKenzie D, Arendt A, Hargrave P, McDowell JH, Molday RS (1984) Localization of binding sites for carboxyl terminal specific anti-rhodopsin monoclonal antibodies using synthetic peptides. Biochemistry 23:65446549. CrossRef Medline

Mazelova J, Astuto-Gribble L, Inoue H, Tam BM, Schonteich E, Prekeris R, Moritz OL, Randazzo PA, Deretic D (2009) Ciliary targeting motif VxPx directs assembly of a trafficking module through Arf4. EMBO J 28:183192. CrossRef Medline

Mollenhauer HH, Morré DJ, Rowe LD (1990) Alteration of intracellular traffic by monensin; mechanism, specificity and relationship to toxicity. Biochim Biophys Acta 1031:225-246. CrossRef Medline

Moritz OL, Tam BM, Papermaster DS, Nakayama T (2001) A functional rhodopsin-green fluorescent protein fusion protein localizes correctly in transgenic Xenopus laevis retinal rods and is expressed in a timedependent pattern. J Biol Chem 276:28242-28251. CrossRef Medline

Muller-Weeks S, Boesze-Battaglia K, Fitzgerald C (2002) Deletional analysis of the rod photoreceptor cell peripherin/RDS carboxy-terminal region. Exp Eye Res 75:143-154. CrossRef Medline

Nebenführ A, Ritzenthaler C, Robinson DG (2002) Brefeldin A: deciphering an enigmatic inhibitor of secretion. Plant Physiology 130:1102-1108. CrossRef Medline

Nieland TJ, Feng Y, Brown JX, Chuang TD, Buckett PD, Wang J, Xie XS, McGraw TE, Kirchhausen T, Wessling-Resnick M (2004) Chemical genetic screening identifies sulfonamides that raise organellar $\mathrm{pH}$ and interfere with membrane traffic. Traffic 5:478-492. CrossRef Medline

Nieuwkoop PD, Faber J (1967) Normal table for Xenopus laevis (Daudin): a systematical and chronological survey of the development from the fertilized egg till the end of metamorphosis, Ed 2. Amsterdam: North-Holland.

Poetsch A, Molday LL, Molday RS (2001) The cGMP-gated channel and related glutamic acid-rich proteins interact with peripherin- 2 at the rim region of rod photoreceptor disc membranes. J Biol Chem 276:4800948016. CrossRef Medline
Rabouille C, Hui N, Hunte F, Kieckbusch R, Berger EG, Warren G, Nilsson T (1995) Mapping the distribution of Golgi enzymes involved in the construction of complex oligosaccharides. J Cell Sci 108:1617-1627. Medline

Ritter LM, Khattree N, Tam B, Moritz OL, Schmitz F, Goldberg AF (2011) In situ visualization of protein interactions in sensory neurons: glutamic acid-rich proteins (GARPs) play differential roles for photoreceptor outer segment scaffolding. J Neurosci 31:11231-11243. CrossRef Medline

Salinas RY, Baker SA, Gospe SM 3rd, Arshavsky VY (2013) A single valine residue plays an essential role in peripherin/rds targeting to photoreceptor outer segments. PLoS One 8:e54292. CrossRef Medline

Scheel J, Pepperkok R, Lowe M, Griffiths G, Kreis TE (1997) Dissociation of coatomer from membranes is required for brefeldin A-induced transfer of Golgi enzymes to the endoplasmic reticulum. J Cell Biol 137:319-333. CrossRef Medline

Schotman H, Karhinen L, Rabouille C (2008) dGRASP-mediated noncanonical integrin secretion is required for Drosophila epithelial remodeling. Dev Cell 14:171-182. CrossRef Medline

Smith SJ, Fairclough L, Latinkic BV, Sparrow DB, Mohun TJ (2006) Xenopus laevis transgenesis by sperm nuclear injection. Nat Protoc 1:21952203. CrossRef Medline

Stefano FP, Krouse J, Marta P, Boesze-Battaglia K (2002) Heterologous expression of WT and mutant photoreceptor peripherin/rds in Madin Darby canine kidney cells: an assessment of fusogenic function. Exp Eye Res 74:267-283. CrossRef Medline

Tam BM, Moritz OL, Papermaster DS (2004) The C terminus of peripherin/ rds participates in rod outer segment targeting and alignment of disk incisures. Mol Biol Cell 15:2027-2037. CrossRef Medline

Tam BM, Xie G, Oprian DD, Moritz OL (2006) Mislocalized rhodopsin does not require activation to cause retinal degeneration and neurite outgrowth in Xenopus laevis. J Neurosci 26:203-209. CrossRef Medline

Tian G, Zhou Y, Hajkova D, Miyagi M, Dinculescu A, Hauswirth WW, Palczewski K, Geng R, Alagramam KN, Isosomppi J, Sankila EM, Flannery JG, Imanishi Y (2009) Clarin-1, encoded by the Usher Syndrome III causative gene, forms a membranous microdomain: possible role of clarin-1 in organizing the actin cytoskeleton. J Biol Chem 284:18980-18993. CrossRef Medline

Travis GH, Brennan MB, Danielson PE, Kozak CA, Sutcliffe JG (1989) Identification of a photoreceptor-specific mRNA encoded by the gene responsible for retinal degeneration slow (rds). Nature 338:70-73. CrossRef Medline

Trivedi D, Colin E, Louie CM, Williams DS (2012) Live-cell imaging evidence for the ciliary transport of rod photoreceptor opsin by heterotrimeric kinesin-2. J Neurosci 32:10587-10593. CrossRef Medline

van Nie R, Iványi D, Démant P (1978) A new H-2-linked mutation, rds, causing retinal degeneration in the mouse. Tissue Antigens 12:106-108. CrossRef Medline

Velasco A, Hendricks L, Moremen KW, Tulsiani DR, Touster O, Farquhar MG (1993) Cell type-dependent variations in the subcellular distribution of alpha-mannosidase I and II. J Cell Biol 122:39-51. CrossRef Medline

Wang J, Morita Y, Mazelova J, Deretic D (2012) The Arf GAP ASAP1 provides a platform to regulate Arf4- and Rab11-Rab8-mediated ciliary receptor targeting. EMBO J 31:4057-4071. CrossRef Medline

Yoo JS, Moyer BD, Bannykh S, Yoo HM, Riordan JR, Balch WE (2002) Non-conventional trafficking of the cystic fibrosis transmembrane conductance regulator through the early secretory pathway. J Biol Chem 277:11401-11409. CrossRef Medline

Zhang Y, Molday LL, Molday RS, Sarfare SS, Woodruff ML, Fain GL, Kraft TW, Pittler SJ (2009) Knockout of GARPs and the beta-subunit of the rod cGMP-gated channel disrupts disk morphogenesis and rod outer segment structural integrity. J Cell Sci 122:1192-1200. CrossRef Medline

Zhao C, Malicki J (2011) Nephrocystins and MKS proteins interact with IFT particle and facilitate transport of selected ciliary cargos. EMBO J 30: 2532-2544. CrossRef Medline 